\title{
Cellular sources of TSPO expression in healthy and diseased brain
}

\author{
Erik Nutma ${ }^{1} \cdot$ Kelly Ceyzériat ${ }^{2,3,4} \cdot$ Sandra Amor ${ }^{1,5} \cdot$ Stergios Tsartsalis $^{2,6} \cdot$ Philippe Millet $^{2,7} \cdot$ David R. Owen $^{6}$. \\ Vassilios Papadopoulos ${ }^{8} \cdot$ Benjamin B. Tournier $^{2,7}$ (D)
}

Received: 15 October 2020 / Accepted: 13 December 2020 / Published online: 12 January 2021

(C) The Author(s) 2021

\begin{abstract}
The $18 \mathrm{kDa}$ translocator protein (TSPO) is a highly conserved protein located in the outer mitochondrial membrane. TSPO binding, as measured with positron emission tomography (PET), is considered an in vivo marker of neuroinflammation. Indeed, TSPO expression is altered in neurodegenerative, neuroinflammatory, and neuropsychiatric diseases. In PET studies, the TSPO signal is often viewed as a marker of microglial cell activity. However, there is little evidence in support of a microglia-specific TSPO expression. This review describes the cellular sources and functions of TSPO in animal models of disease and human studies, in health, and in central nervous system diseases. A discussion of methods of analysis and of quantification of TSPO is also presented. Overall, it appears that the alterations of TSPO binding, their cellular underpinnings, and the functional significance of such alterations depend on many factors, notably the pathology or the animal model under study, the disease stage, and the involved brain regions. Thus, further studies are needed to fully determine how changes in TSPO binding occur at the cellular level with the ultimate goal of revealing potential therapeutic pathways.
\end{abstract}

Keywords TSPO $\cdot$ Astrocytes $\cdot$ Microglia $\cdot$ Positron emission tomography

\section{Introduction}

The $18 \mathrm{kDa}$ translocator protein (TSPO) is increasingly used as a marker for in vivo neuroinflammation with positron emission tomography (PET) in a wide variety of CNS diseases. Many of these studies reveal that TSPO PET signal is altered in neurodegenerative, neuroinflammatory, and neuropsychiatric diseases when compared to healthy individuals [1]. Historically, TSPO has been viewed as a marker of microglial cell activity. Indeed, the first studies showing a correlation

This article is part of the Topical Collection on Translational research

Benjamin B. Tournier

benjamin.tournier@hcuge.ch

1 Department of Pathology, Amsterdam UMC, VUmc, Amsterdam, The Netherlands

2 Division of Adult Psychiatry, Department of Psychiatry, University Hospitals of Geneva, Avenue de la Roseraie, 64, 1206 Geneva, Switzerland

3 Division of Nuclear medicine and Molecular Imaging, University Hospitals of Geneva, Geneva, Switzerland

4 Division of Radiation Oncology, Department of Oncology, University Hospitals of Geneva, Geneva, Switzerland between the binding of one of the TSPO tracers and microglia speculated that TSPO is a marker for pathogenic microglial cells $[2,3]$. This idea is no longer maintained. Indeed, the presence of TSPO in other cell types, notably astrocytes and endothelial cells, has been demonstrated [4-7].

TSPO is not the only molecular target for PET imaging of neuroinflammation. Several other receptors that are expressed in brain cells and are potentially upregulated in neuroinflammation have been identified and specific radiotracers are developed to label them in vivo. For instance, radiotracers

5 Centre for Neuroscience and Trauma, Blizard Institute, Barts and the London School of Medicine \& Dentistry, Queen Mary University of London, London, UK

6 Department of Brain Sciences, Faculty of Medicine, Imperial College London, London, UK

7 Department of Psychiatry, University of Geneva, Geneva, Switzerland

8 Department of Pharmacology and Pharmaceutical Sciences, School of Pharmacy, University of Southern California, Los Angeles, CA, USA 
binding the cannabinoid receptor $2\left(\mathrm{CB}_{2}\right)$ receptor $[8,9]$ and cyclooxygenase-2 (COX-2) $[10,11]$ have been validated in preclinical models of brain disease and generally showed a robust increase in binding associated with neuroinflammation, while the first results from human PET studies are encouraging $[12,13]$. In addition, radiotracers binding the purinergic receptor subtype 7 (P2X7) [14-16], the sphingosine-1phosphate receptor 1 (S1PR1) [17], reactive oxygen species [18], and the colony stimulating factor 1 receptor (CSF1R) [19] are at initial stages of preclinical validation. In light of these results, it is clear that TSPO is the most extensively studied molecular target for in vivo PET imaging of neuroinflammation to date.

Here we review the cellular sources and functions of TSPO in animal models and humans in health and in CNS diseases. This will contribute to a better understanding of the function of TSPO, the physiology of TSPO expression, and its functional consequences in the human body and the CNS. Furthermore, knowledge about the expression of TSPO in CNS diseases provides insight into expression patterns and its predictive potential in diagnosing CNS diseases and disease progression with TSPO PET.

\section{TSPO functions in health}

TSPO participates in many essential mitochondria-based physiological processes, including metabolism and cellular bioenergetics, mitochondrial respiration, cholesterol transport and steroidogenesis, immunomodulation, porphyrin transport, and heme biosynthesis [20-24]. It has also been suggested that TSPO may play critical roles in cell proliferation, tumorigenesis, and apoptosis [24-26]. In order to discern and evaluate the function of any protein, particularly one like TSPO that seems to be multifunctional, one must consider specific characteristics that could provide clues to the possible roles it may play. The characteristics that need to be investigated should include its (i) tissue, cellular, and subcellular localization, (ii) characteristics and effects of endogenous and exogenous ligands, (iii) molecular structure and cellular functions, (iv) genetics and genetic models, and (v) evolution.

\section{Tissue, cellular, and subcellular localization}

TSPO was first characterized for its ability to bind with specificity and high-affinity various classes of chemicals such as benzodiazepines, isoquinoline carboxamides, indole acetamides, pyrazolopyrimidines, and aryloxyanilides, as well as endogenous ligands including porphyrins, the endozepine diazepam binding inhibitor [20-24, 27-33]. Radioligand binding and later on immunodetection studies revealed that the distribution pattern of TSPO between rodents and humans is similar; secretory and glandular tissues were particularly rich in TSPO. These studies also indicated that although TSPO is present in most tissues in most species at various levels of expression, it is most abundant in steroid-synthesizing adrenal and gonadal tissues. The heart and kidney express intermediate levels of TSPO, while lower levels are found in the liver and brain. Interestingly, when considering the mitochondrial content of each tissue, there is not always a clear correlation between TSPO levels and mitochondrial content. This finding suggests that tissue- and cell-specific factors regulating TSPO gene expression are driving TSPO content rather than factors driving mitochondria formation.

Steady-state mRNA profiling shows that TSPO mRNA is present in all tissues and correlates well with reported protein expression levels [25]. Moreover, the expression patterns of mouse TSPO were found to be well-correlated and similar to that reported for human $\operatorname{TSPO}[34,35]$.

TSPO levels were found to be elevated in cancer cell lines and numerous cancers suggesting a role for TSPO in cell proliferation and carcinogenesis $[24,25,29$, 36-38]. Increased TSPO levels in cancer are due to gene amplification; $\mathrm{Sp} 1, \mathrm{Sp} 3$, and $\mathrm{Sp} 4$ transcription factor regulation of constitutive TSPO expression; and epigenetic modifications of the proximal promoter and first intron $[25,39,40]$.

TSPO is an integral outer mitochondrial membrane protein spanning the membrane through its $5 \alpha$-helical domains [41-54]. While TSPO is a nuclear encoded protein, unlike most mitochondrial proteins, TSPO does not possess a mitochondrial targeting sequence, although it contains information on the $\mathrm{C}$-terminus that is essential for its mitochondrial import [55]. After integration into the OMM, TSPO forms dimers and sometimes polymers $[20,56,57]$ at the outer and inner mitochondrial membrane contact sites where it becomes part of a larger protein complex [58]. This complex includes the OMM voltage-dependent anion channel 1 (VDAC1); ATPase family AAA domain-containing protein 3 (ATAD3), a protein that spans across the mitochondrial membranes, and in steroidogenic cells; and the inner mitochondrial membrane cytochrome P450 side-chain cleavage enzyme (CYP11A1), among others [58, 59]. In addition, cytosolic, endoplasmic reticulum and Golgi proteins have been shown to associate with TSPO to form functional complexes [59-61]. When assembled together, these proteins function as a signal transduction complex, or "transduceosome" mediating the transmission of information to mitochondrial TSPO.

Although $95 \%$ of TSPO is found in the mitochondria, the protein can be found in intracellular locations other than mitochondria, such as the (peri)nuclear region and plasma membrane, likely playing different functions. Nevertheless, non-mitochondrial TSPO [43, 62] has received little attention so far. 


\section{Characteristics and effects of endogenous and exogenous ligands}

TSPO is involved primarily in the mitochondria of steroid synthesizing cells. Steroidogenesis in the mitochondria begins with the transport of substrate cholesterol from intracellular stores into the mitochondria. Therefore, the role or roles of TSPO in mitochondrial steroidogenesis and cholesterol transport, in particular, were investigated.

With the availability of high-affinity TSPO ligands, the function of TSPO in various tissues was explored, aiming to assess whether these ligands could affect mitochondrial function, including steroid production. Several TSPO ligands were found to affect mitochondrial respiration [63] and increase oxygen consumption [64] and ATP synthesis [65]. At the same time, detailed studies demonstrated the ability of these ligands to induce cholesterol transport into mitochondria and steroid formation in all steroidogenic cells in vitro and in vivo $[56,66,67]$. These studies were later extended to neurosteroid synthesizing glia cells in the brain [68-71]. TSPO ligands were also shown to affect intracellular cholesterol trafficking and lipid droplet accumulation, a function that may not be related to steroidogenesis $[72,73]$.

However, there are ligand-specific differences as well as off-target effects. These differences may be explained by the tissue and cell-specific microenvironment and the presence of endogenous ligands, e.g., porphyrins and endozepines, in specific tissues/cells that may compete with the exogenous ligand. Moreover, the fact that TSPO exists within large protein complexes suggests that TSPO ligand selectivity may be governed by the protein-complex composition and not only by the interaction with TSPO alone [74]. In addition, it was recently shown that TSPO ligands have different occupancy times for TSPO and this affects their ability to induce steroid formation [75, 76]. Concerning the off-target effects, most of the time these are linked to the use of high concentrations of TSPO ligands, thousands of time higher than the affinity of these compounds for TSPO. Indeed, lipophilic TSPO ligands used at high concentrations are likely to interact with membranes or other not yet identified targets resulting in off-target effects [66, 77]. In addition, TSPO ligands were found to exert cell-type specific effects raising again the question of the role of the microenvironment, ligand residence time, and the presence of endogenous ligands [78, 79].

Over the years, the effects of TSPO drug ligands with various mitochondrial activities/functions have also been shown, including changes in VDAC1, F-ATP synthase and ANT activities, modulation of reactive oxygen species (ROS) production, and calcium levels and effects on mitochondrial membrane potential and permeability transition pore (MPTP) [51, $52,59,80-85]$. These effects were found to be tissue- and cellspecific and sometimes ligand-specific or observed only in cell lines. However, in some cases, the effects were observed in the presence of micromolar concentrations of TSPO ligands, far beyond the affinity of the protein for the compounds. The complex formed by the mitochondrial TSPO in association with VDAC1 has been suggested to have a role in apoptosis, possibly through MPTP opening, and cholesterol transport. TSPO drug ligands have been found to exert both proliferative and antiapoptotic effects, as well as antiproliferative properties, acting in a biphasic manner $[24,25,29$, $36-38,86]$.

\section{Molecular structure and cellular functions}

The drug ligand binding domains of TSPO have been mapped [87] and it was subsequently shown that TSPO is a highaffinity cholesterol binding protein containing a conserved cholesterol recognition amino acid consensus domain in the C-terminus $[88,89]$. The drug and cholesterol binding domains were found to be in distinct domains of the protein results confirmed by NMR $[87,88,90]$. Moreover, these findings were further confirmed in structural studies by NMR and crystallography studies that reported the atomic structure of TSPO [91-96]. These studies also proposed that the functional TSPO is a dimer, that ligand binding to TSPO can promote cholesterol movement, and that cholesterol is an allosteric regulator of TSPO [91, 93, 94, 97].

The ability of TSPO to bind drug ligands and cholesterol is its two major intrinsic properties and mostly likely the ones determining its function. We summarized above the reported effects of TSPO ligands on mitochondrial function. Although in steroidogenic and liver cells the role of a cholesterol binding protein segregating the steroidogenic pool of cholesterol from structural cholesterol and facilitating its import into the mitochondria for steroid and formation is obvious, for other cells it is not so clear. However, cholesterol transfer in the inner mitochondrial membrane is needed for biogenesis of mitochondrial membranes during cell proliferation and/or repair. TSPO may also function as a sink for cholesterol which when free could be toxic for the cells. It is also possible that TSPO may be facilitating the movement of free cholesterol from the mitochondria to other organelles, as shown in astrocytes [72], fibroblasts [72], macrophages [98], retinal cells [99], and the steroidogenic Leydig cells [73]. Moreover, TSPO-mediated accumulation of free cholesterol in the mitochondria may affect mitochondrial membrane fluidity/permeability, fission/fusion processes, membrane protein/ transporter function(s), and/or membrane potential [72, 83, 100-102].

TSPO was also shown to regulate mitophagy $[59,103]$. TSPO, by binding to VDAC1, reduces mitochondrial coupling and promotes an overproduction of ROS that counteracts Parkin-mediated ubiquitination of proteins. These data suggested TSPO as an element in the regulation of mitochondrial quality control by autophagy. Further studies showed 
that TSPO deregulates mitochondrial $\mathrm{Ca}^{2+}$ signaling, leading to a parallel increase in the cytosolic $\mathrm{Ca}^{2+}$ pools that activate the $\mathrm{Ca}^{2+}$-dependent NADPH oxidase, thereby increasing ROS [104]. The inhibition of mitochondrial $\mathrm{Ca}^{2+}$ uptake by TSPO is a consequence of the phosphorylation of VDAC1 by PKA, which is recruited to the mitochondria by ACBD3, VDAC1, ACBD3, PKA, and all transduceosome components recruited at TSPO. This is proposed as a novel OMM-based pathway to control intracellular $\mathrm{Ca}^{2+}$ dynamics and redox transients in cytotoxicity [104].

\section{Genetics and genetic models}

A series of articles came out in the last 15 years assessing the direct role of TSPO in various cellular pathways. First, the role of TSPO in opening the MPTP in liver mitochondrial function was investigated in an animal model depleted of liver TSPO [105]. The data obtained showed that the absence of TSPO does not affect liver MPTP function. Then, studies in rodents with genetic depletion of TSPO led to conflicting results including no effect on steroid synthesis [106-108], reduced steroid output, inhibition of corticosteroid response to adrenocorticotropic hormone, changes in lipid homeostasis in Leydig cells and reduction of circulating testosterone levels, and suppression of neurosteroid formation [109-112].

In addition, discordant data was reported on MA-10 mouse Leydig cells. Knockdown of TSPO expression using antisense oligonucleotides or antisense RNA reduces the ability of the cells to form steroids, while CRISPR/Cas9-guided TSPO deletion has either no effect or abolishes steroid synthesis [113-116]. These differences have been discussed in detail in other reviews $[66,67]$.

Among all these studies, it seems that there is consistency between laboratories on the role of TSPO in neurosteroid formation where genetic deletion of TSPO led to reduced neurosteroid synthesis $[110,112]$. These results suggest that the role of TSPO in steroid formation may be primary and rate-determining in cells where steroid formation is independent on hormonal control, e.g., brain, compared to the classical peripheral steroid forming gonads and adrenal where pituitary hormones control the massive steroid production. In peripheral steroidogenic organs, TSPO may play a secondary role or play a role in cases where the cells do not respond to pituitary hormones, as in male hypogonadism where TSPO ligands can recover the drug- or age-induced reduction in androgen formation [66].

Numerous biochemical, pharmacological, and clinical data in the field of photodynamic therapy in oncology have demonstrated the role of ability of TSPO to bind porphyrins and its role in porphyrin and heme transport and synthesis [117-119]. Using the same mice as before [107], the same group failed to show a role for TSPO in porphyrin and heme biosynthesis or transport [120].
TSPO deficiency decreased the oxygen consumption rate and mitochondrial membrane potential in mouse fibroblasts [120], MA-10 mouse Leydig cells [116], and C20 human microglia cells where it also reduced respiratory function [121]. Mitochondrial membrane potential depends on the flux of respiratory substrates adenosine triphosphate, adenosine diphosphate, and Pi through VDAC. Adenine nucleotide translocator also plays a role in maintenance of the membrane potential [116]. Therefore, TSPO likely controls cellular and mitochondrial metabolism via regulation of the mitochondrial membrane potential and affects OMM permeability and/or outer and inner membrane contacts/fusion.

Interestingly, lack of TSPO was shown to affect mitochondrial respiration and increase oxygen consumption in some cell and animal Tspo KO models, but not in others [63, 65, $79,107,108,120,121]$. More recent studies also failed to show a direct link of TSPO to F-ATP synthase, which was shown to form the MPTP [122].

The differences underlying the disparate results from these genetic animal and cell models are not well understood. However, they clearly indicate differences between the pharmacology of TSPO and its intrinsic cellular functions. It is also likely that species differences, the presence of external or intrinsic stimuli, as well as differences in age, sex, and metabolic status of the species used may control the expression of TSPO. Considering that TSPO is one of the evolutionarily oldest proteins (see below), we proposed that it serves as the basis for fundamental functions and, thus, in case of its absence, compensatory mechanisms may have evolved. Moreover, even if its absence may not always affect animal phenotype, its presence, concentrated at the OMM, plays a regulatory role in mitochondrial function and associated tissue-specific phenotypes. Moreover, its presence provides us with a molecular target able to modulate mitochondrial and cell functions.

TSPO genetics in humans provide some of the most important information on the function of this protein. No humans have been identified lacking TSPO. In humans, the presence of a number of polymorphisms have been identified in the TSPO gene, including rs6971 [123]. This polymorphism causes a non-conservative amino acid substitution, Ala147Thr, resulting in altered binding affinity of TSPO for specific ligands [123]. The presence of this TSPO polymorphism has been linked to the function of the hypothalamicpituitary-adrenal axis, predisposing carriers to psychiatric disorders [124-127], and potentially impairing the response of patients to anxiolytic TSPO drug ligands $[128,129]$. The presence of this TSPO polymorphism was linked to reduced pregnenolone [130] and adrenocorticotropic hormone (ACTH)-induced corticosteroid levels [110] and shown to be associated with dysregulated cortisol rhythms and consequent clinical exacerbations in bipolar disorders [131]. This finding provides clear evidence of the link between TSPO, cholesterol binding, and steroid formation under normal and stress conditions. 


\section{Evolution}

TSPO is an evolutionary conserved 3.5-billion-year-old protein [132]. TspO, named for its high tryptophan content and apparent role in the regulation of the transition between photosynthesis and respiration, is the mammalian TSPO ortholog in the photosynthetic bacterium Rhodobacter [133], a close living relative of mitochondria [57]. Detailed evolutionary studies indicated that the Tspo gene family has been expanded by gene duplications from a bacterial environmental sensor or signal transducer to a functional bioregulator adapted to organism-, tissue-, cell-, and organelle-specific needs. Interestingly, the mammalian protein is able to rescue the phenotypes of bacterial $T_{s p O} \mathrm{KO}$ suggesting a conserved function [134] and that one compensates for the loss of oxygen sensing function that occurs when the other is depleted.

An additional Tspo family member, Tspo2, has been characterized [135]. Comparative analysis of Tspo1, the first family member to be identified, and Tspo 2 structure and function indicates that TSPO2 was characterized by the loss of diagnostic drug ligand binding, but retention of cholesterol binding properties, and is involved in cholesterol redistribution during erythropoiesis [135]. Whether there are additional family members in mammals or humans remains to be determined. However, the highly conserved sequence would seem to indicate that such expansion in members was not needed to support the rich expansion of cellular functions.

Pharmacological and structural evidence supports TSPO functioning in tetrapyrrole biosynthesis, porphyrin transport, heme metabolism, cholesterol transport/trafficking, steroid formation, control of ROS levels, and the protection of mitochondria from free radical damage. All evolutionarily conserved functions are linked to mitochondria and affected by changes in mitochondrial membrane potential, a function dependent on the presence of TSPO. Few years ago, we proposed that the central role of TSPO throughout evolution is in oxygen-mediated metabolism. This central function has diversified roles in tissue- and cell-specific signaling, metabolism, cholesterol trafficking, immunological responses, apoptosis, steroid synthesis, and host-defense response to disease and injury, all oxygen-mediated pathways [22, 132].

\section{Summary}

TSPO is a multifunctional protein involved in a wide array of cellular functions that are essential for human health. Its central location in the mitochondria, a multifunctional organelle itself, underscores its importance at the crossroads of critical homeostatic pathways. Its evolutionarily conserved sequence also supports its cellular significance. As we continue to elucidate the intricacies of the role of TSPO in health and disease, we will have the opportunity to identify new therapeutic and diagnostic targets that will have significant impact in the near and long term.

\section{TSPO cell origin in wild-type and preclinical models of neurological disease}

A summary of the cell origin of TSPO according to the pathology is given in Table 1 .

\section{Wild-type}

The density and cell origin of TSPO were assessed in the mouse brain. The specificity of TSPO staining was confirmed using a TSPO-deficient strain [136]. Two major findings were reported: TSPO is not homogeneously expressed in the various brain regions and the cell origin also varies across brain regions. The cerebellum shows high levels of TSPO staining as does the choroid plexus and the ependyma of the ventricular system. In addition, TSPO expression in the white matter is generally higher than in the gray matter. Regarding the cell origin of TSPO, in the cortex, astrocytes and microglia lack the constitutive TSPO expression observed in white matter. In contrast, in the hippocampus, TSPO is predominantly present in the subgranular layer and partially colocalizes with astrocytes but not with microglia. In the cerebellum, Purkinje cells are responsible for the expression of TSPO. Endothelial cells and pericytes of blood vessels also express TSPO. Furthermore, TSPO-positive NG2 cells were found in the spinal cord of mice (Daugherty et al., 2013). Finally, TSPO seems to be absent from neurons and oligodendrocytes in all brain regions. However, a recent study shows a strong colocalization between TSPO and tyrosine hydroxylase (the limiting enzyme of dopamine synthesis) in the substantia nigra [137]. The authors concluded of that study that TSPO is present in the neurons of the dopaminergic system.

\section{CNTF and TNF}

Numerous studies have sought to highlight the alterations in its expression in response to either inflammatory stimuli. A first study evaluated the response to the overexpression of the ciliary neurotrophic factor (CNTF) [138]. The authors administered a lentivirus coding for the CNTF (containing an export sequence to be released outside the cell) via an intracerebral injection to focally induce an artificial expression of the CNTF in the brain. Two to six months after the injection, a significant increase in TSPO binding was observed on the ipsilateral side in PET imaging, which was confirmed ex vivo by western blotting and mRNA quantification. In order to characterize the cells that accounted for this upregulation, double immunofluorescence was performed for TSPO, IBA1 (a marker of microglia), and GFAP (a marker of astrocytes). In the 
Table 1 TSPO cell origin in preclinical models of neurological diseases

\begin{tabular}{llllll}
\hline Human use & Preclinical model & Microglia & Astrocytes & Endothelial cells & References \\
\hline Acute inflammation & LV-CNTF & $\mathrm{x}$ & $\mathrm{x}$ & $\mathrm{x}$ & {$[138]$} \\
& AAV-TNF & $\mathrm{x}$ & $\mathrm{x}$ & $\mathrm{x}$ & {$[139]$} \\
Ischemia & MCAO & $\mathrm{x}$ & $\mathrm{x}$ & & {$[141-143]$} \\
Multiple sclerosis & EAE & $\mathrm{x}$ & & {$[146,150]$} \\
& EAE in TSPOko & & $\mathrm{x}$ & {$[149]$} \\
& CPZ & $\mathrm{x}$ & $\mathrm{x}$ & {$[147,148]$} \\
Alzheimer's disease & APP23 & & $\mathrm{x}$ & {$[153]$} \\
& PS19 & $\mathrm{x}$ & & {$[153]$} \\
& APP & $\mathrm{x}$ & {$[151,154]$} \\
& APPNL-GSEN1 & $\mathrm{x}$ & $\mathrm{x}$ & & {$[157]$} \\
& $3 \mathrm{xTg}-\mathrm{AD}$ & $\mathrm{x}$ & $\mathrm{x}$ & & {$[159]$} \\
Schizophrenia & 5xFAD & $\mathrm{x}$ & & $\mathrm{x}$ & {$[154,155]$} \\
\hline
\end{tabular}

$L V$-CNTF lentivirus encoding ciliary neurotrophic factor, $A A V$ - $T N F$ adeno-associated virus encoding tumor necrosis factor, $M C A O$ middle cerebral artery occlusion, $E A E$ experimental autoimmune encephalomyelitis, TSPOko $18 \mathrm{kDa}$ translocator protein knockout, $C P Z$ cuprizone, APP amyloid precursor protein, $P S E N$ presenilin, $3 x T g$ triple transgenic model, $5 x F A D$ five AD-linked mutation model, MIA maternal immune activation model contralateral (vehicle-treated) side, TSPO was found in microglial cells but not in astrocytes. Conversely, on the ipsilateral side, TSPO was localized in microglia as well as astrocytes indicating that CNTF induced TSPO in astrocytes. In contrast, in microglia, it is difficult to conclude whether a modification of the TSPO has taken place or not, in the absence of quantification. Indeed, although the TSPO is present on both sides of the brain (treated and control), it is possible that its level is increased in response to the chronic CNTF exposure. In a second study using a similar approach, an adenovirus encoding the sequence of the tumor necrosis factor (TNF) gene was injected into the mouse brain and analyses were performed at 3 or 5 days post injection [139]. Colocalization studies demonstrated the presence of TSPO in astrocytes and microglia. In addition, compared to the non-injected side, there was an increase in the number of double-positive cells for TSPO with GFAP, CD11b (a microglial marker), as well as CD31 (an endothelial marker), as revealed by flow cytometry.

\section{Ischemia}

One of the most popular animal models of ischemia is achieved by a unilateral occlusion of the middle cerebral artery (MCAO) [140]. This intervention induces a progressive inflammatory reaction that is associated with an increase in TSPO at the mRNA and protein levels [141, 142]. To determine the cellular origin of TSPO in this experimental model, 1 week after a 60 -min intraluminal occlusion of $\mathrm{MCA}^{-} \mathrm{TSPO}^{+}$ labeling was reported in microglial cells (as shown by lectin immunoreactivity) at the site of the core of the ischemia [142].
At the periphery of the ischemic core, some of the GFAP ${ }^{+}$ cells were also $\mathrm{TSPO}^{+}$, compared with the contralateral side. Using a similar protocol but with an occlusion time of $90 \mathrm{~min}$, there was a strong $\mathrm{TSPO}^{+} \mathrm{CD} 11 \mathrm{~b}^{+}$colocalization indicative of a microglial origin of TSPO [141]. However, these data are qualitative and an assessment of the colocalization between TSPO and other cell-type markers was not performed. A third study showed an increase in the number of $\mathrm{TSPO}^{+}$cells in response to the occlusion of MCA as demonstrated by cytometry [143]. More precisely, the $\mathrm{TSPO}^{+}$cells expressed microglial markers $\left(\mathrm{Cd} 11 \mathrm{~b}^{+} \mathrm{CD} 45^{\text {int }}\right.$ or $\left.\mathrm{IBA} 1^{+}\right)$. Interestingly, pretreatment with the TSPO agonist etifoxine helped to contain the size of ischemia, decreased neurological symptoms, and reduced cytokine release in response to the MCAO. These effects were abolished in a model of ischemia combined with a chemical inactivation of microglia [143]. Thus, it is probable that TSPO from microglia plays a role in inflammation in MCAO models. However, the search for TSPO in other cell types is not constant and will therefore require further investigations to better define, for example, the role of TSPO of astrocytic origin.

\section{Multiple sclerosis}

Experimental autoimmune encephalomyelitis (EAE) and cuprizone (CPZ) intoxication models induce demyelination and proliferation of microglial and astrocytic cells and are thus useful animal models of multiple sclerosis (MS) [144, 145]. An increase in TSPO density has been reported in such animal models, using TSPO radioligands $\left(\left[{ }^{3} \mathrm{H}\right](\mathrm{R})-\mathrm{PK} 11195\right.$, $\left.\left[{ }^{18} \mathrm{~F}\right] \mathrm{DPA}-714,\left[{ }^{18} \mathrm{~F}\right] \mathrm{GE} 180\right)$ [146-148]. By assessing the 
colocalization between TSPO and IBA1 or GFAP after exposure to CPZ (administered per os in the animals' food) for 1, 3 or 5 weeks, virtually all IBA $1^{+}$cells expressed TSPO in both control and CPZ-treated animal. In contrast, only a small portion of $\mathrm{GFAP}^{+}$were $\mathrm{TSPO}^{+}$positive in control animals, whereas about $35 \%$ of $\mathrm{GFAP}^{+}$cells become $\mathrm{TSPO}^{+}$after 5 weeks of treatment. These changes were mainly localized in the corpus callosum and, to a lesser extent, in the gray matter cortex [147]. The CPZ models make it possible to investigate the expression of TSPO during the demyelinating phase (during CPZ treatment), as well as during the remyelination phase (after CPZ treatment). Thus, Zinnhardt et al. (2019) used a 4and a 6-week CPZ treatment to explore both phases of the CPZ treatment [148]. They observed increases in TSPO binding in both states compared with the controls. TSPO levels in the demyelination phase are higher than during the remyelination phase. TSPO expression was mainly microglial during the demyelination phase and both microglial and astrocytic during the remyelination phase. These results were based on the colocalization of $\mathrm{TSPO}^{+} \mathrm{IBA}^{+}$and $\mathrm{TSPO}^{+} \mathrm{GFAP}^{+}$, a qualitative finding, without precise quantitative information regarding the relative contribution of these two glial cell types in the alterations in TSPO binding. In a mouse EAE model, photoemulsion of the in vitro binding of $\left[{ }^{3} \mathrm{H}\right](\mathrm{R})-\mathrm{PK} 11195$ on brain sections [146] showed that the TSPO radioligand binding was colocalized with OX-42 (a marker of microglia). The authors reported no co-staining between $\left[{ }^{3} \mathrm{H}\right](\mathrm{R})-\mathrm{PK} 11195$ and GFAP. However, in a mouse model of specific TSPO deficiency in astrocytes (hGFAP-driven conditional TSPO knockout mice), the astrocytic proliferation and the behavioral signs, both associated with EAE, were milder, compared to wild-type animals [149]. Importantly, treatment with the TSPO ligand etifoxine decreases the severity and increases the symptomatic recovery in a EAE mouse model of MS [150]. These findings suggest that the microglial and astrocytic TSPO differentially contribute to animal models of MS.

\section{Alzheimer's disease}

Alzheimer's disease (AD) is characterized by the accumulation of amyloid deposits mainly formed by the beta amyloid peptide $(A \beta)$ and by the presence of neurofibrillary tangles formed from abnormal forms of the Tau protein. Animal genetic models of the disease are produced by the induction of $\mathrm{A} \beta$ overexpression (by adding transgenes encoding human forms of APP or PS1) or overexpression of abnormal forms of Tau (by adding transgenes coding for human Tau forms) [151]. In all AD models, an overexpression of TSPO is observed [3, 6, 152-159]. However, there is no consensus on the cellular origin of TSPO [160]. Indeed, in the APP23 transgenic $(\mathrm{Tg})$ mice model, astrocytes represent the cellular source of TSPO expression in the vicinity of extracellular amyloid deposits [153]. In contrast to this model, the PS19 Tg mice show microglia TSPO expression [153]. The presence of a significant spatial correlation between $\left[{ }^{3} \mathrm{H}\right](\mathrm{R})$-PK11195 binding and IBA1 staining that is not present in the case of GFAP staining suggests that the origin of TSPO is predominantly microglial in the $\mathrm{APP}_{\mathrm{SWE}} / \mathrm{PSEN}_{\triangle \mathrm{E} 9}$ mice model [3]. However, double immunofluorescence revealed that the cellular origin of TSPO may mainly be microglial although $\mathrm{TSPO}^{+} \mathrm{GFAP}^{+}$cells were also present [154]. The predominance of a microglial origin to the TSPO binding is also observed in the $3 \times \mathrm{TgAD}$ model $\left(\mathrm{APP}_{\mathrm{SWE}} / \mathrm{PS} 1_{\mathrm{M} 146 \mathrm{~V}} / \mathrm{Tau}_{\mathrm{P} 301 \mathrm{~L}}\right)$ with the use of IBA1 and GFAP co-staining with TSPO [159]. In a model combining three APP mutations and two PS1 mutations (5XFAD), colocalization of TSPO with GFAP or $\mathrm{S} 100 \beta$ for astrocytes is absent while $\mathrm{TSPO}^{+} \mathrm{IBA}^{+}$cells are observed. Interestingly, Liu et al. (2005) also reported that subtypes of microglial cells are differentially contributing to the expression of TSPO. Indeed, TSPO strongly colocalizes with the CD68 microglial pro-inflammatory marker. In addition, TSPO is also present in microglia positive for the CD206 anti-inflammatory marker when these cells are in the vicinity of the amyloid deposits [154]. Thus, the complexity of glial cell types and the differential expression of TSPO by the various subclasses of glial cells add another level of complexity that needs to be further studied.

\section{Schizophrenia}

In contrast to the aforementioned pathologies, the density of TSPO is decreased in schizophrenia (see details in the next chapter). Using the maternal immune activation (MIA) animal model of schizophrenia, a decrease in the TSPO levels was reported [161]. The authors observed a decrease in colocalization of TSPO with IBA1, GFAP, and Glut1 (a marker of the brain vasculature) [161], suggesting the involvement of multiple different cell types.

\section{General considerations}

Overall, it is important to discuss several critical issues. First, the assessment of TSPO in other cell types than microglia has not been examined systematically, e.g., in astrocytes and even less in endothelial cells. Secondly, many studies use IBA1 as a marker of microglia, but it represents a ubiquitous labeling of this cell type and not of any specific activated forms or phenotypes. Without a more in-depth analysis of the $\mathrm{TSPO}^{+} \mathrm{IBA}^{+}$cells, it cannot be completely affirmed that it is indeed active microglia and even if it is, the pathophysiological significance of a particular phenotype of activated microglia or indeed other cells of the monocyte family that also express IBA1. In this context, several reports using mouse primary glial cell cultures demonstrate that TSPO is more likely to be modified in activated (by pro-inflammatory stimuli) forms of microglia and astrocytes [139, 162, 163]. Finally, 
studies of the number of cells expressing TSPO based on immunofluorescence do not determine if a change in the number of TSPO binding sites per cell is present. Finally, although evidence is scarce, a direct implication of TSPO on the pathophysiology of the various neuropsychiatric conditions may not be ruled out.

\section{TSPO expression in human CNS in health, aging, and neurological disease}

The cell origin of TSPO according to the human pathology is summarized in Table 2.

\section{Health and aging}

Little is known of the distribution and expression of TSPO during development, healthy aging, and how such expression differs in regions of the CNS in humans. Consideration of these features, as well as the mode of analysis, e.g. PET, autoradiography, quantitative assays, or pathology of postmortem (PM) brain, is of key importance to explain TSPO expression in PET imaging.

Much of what is known about TSPO expression in humans comes from PET imaging where differential expression may be due to the different affinity patterns for TSPO ligands. PET studies report an increased expression of TSPO with aging in healthy subjects in several cortical and subcortical areas [164-166]. However, little is known about the levels and cellular expression of TSPO during (early) development or in healthy elderly subjects as determined in postmortem control tissues. Quantitative immunoblotting approaches reveal that TSPO protein levels are 2- to 70-fold higher than those reported by in vitro binding assays and expression is widely distributed in the CNS in gray and white matter at all ages [164]. At birth TSPO protein levels are highest in the frontal cortex possibly reflecting expression in neuronal precursor cells although pathology studies have not yet supported this hypothesis. Levels of TSPO decline in the first 3 months after birth and subsequently increase modestly during adulthood/ senescence [164]. The relatively high binding and protein expression reported in aging may reflect subtle changes due to senescence or, alternatively, due to changes in the morphology or phenotype of aging cells in the CNS parenchyma. Pathology studies on PM tissues of normal human brains reported that a variety of cell types express TSPO, the levels and extent of expression depending on the TSPO antibody used [167]. Endothelial cells, arachnoid cells, cells within the choroid plexus as well as astrocytes, microglia, and to a lesser degree oligodendrocytes and immune cells within blood vessels revealed a punctate expression typical for mitochondrial expression markers [167]. However, these studies were limited to tissues from aged donors and it is difficult to conclude, based on the available pathology studies, that the cellular expression of TSPO in the normal brain is due to normal aging.

\section{Neuroinflammation}

TSPO PET imaging is widely used to monitor inflammation in MS, a chronic inflammatory demyelinating and neurodegenerative disease with onset in young adults [168]. The PET signal in MS is frequently assumed to represent pathogenic microglia yet pathology studies have detailed a more widespread cellular expression. Compared to normal-appearing white matter in MS tissues where TSPO is expressed in scattered HLA+ cells throughout the CNS, the expression is approximately 20-fold higher in active MS lesions and the rim of chronic active lesions [7]. In addition to microglia, this study revealed that expression is also observed in astrocytes, predominantly in chronic active and inactive lesions, and that the astrocyte signal contributes significantly to the active lesions and rim of chronic active lesions. In addition, this study

Table 2 TSPO cell origin in human neurological diseases

\begin{tabular}{|c|c|c|c|c|c|c|c|}
\hline Human disease & & Microglia & Astrocytes & Neurons & $\begin{array}{l}\text { Endothelial } \\
\text { cells }\end{array}$ & $\begin{array}{l}\text { Vascular smooth muscle } \\
\text { cells }\end{array}$ & References \\
\hline Neuroinflammation & Multiple sclerosis & $\mathrm{x}$ & $\mathrm{x}$ & & & & {$[7,169]$} \\
\hline \multirow{2}{*}{$\begin{array}{l}\text { Neurodegenerative } \\
\text { diseases }\end{array}$} & Alzheimer's disease & $\mathrm{x}$ & $\mathrm{x}$ & & $\mathrm{x}$ & $\mathrm{x}$ & {$[172,173]$} \\
\hline & $\begin{array}{l}\text { Dementia with } \\
\text { Lewy-bodies }\end{array}$ & $\mathrm{x}$ & & & & & {$[173]$} \\
\hline \multirow[t]{2}{*}{ Infections } & HIV encephalitis & $\mathrm{x}$ & $\mathrm{x}$ & $\mathrm{x}$ & $\mathrm{x}$ & & {$[167]$} \\
\hline & Creutzfeldt-Jakob & $\mathrm{x}$ & & & & & {$[178]$} \\
\hline $\begin{array}{l}\text { Neuropsychiatric } \\
\text { disorders }\end{array}$ & Major depression & $\mathrm{x}$ & & & & & [184-186] \\
\hline Stroke & & $\mathrm{x}$ & $\mathrm{x}$ & & & & {$[167]$} \\
\hline Epilepsy & & $\mathrm{x}$ & $\mathrm{x}$ & $\mathrm{x}$ & & & {$[188]$} \\
\hline
\end{tabular}

HIV Human immunodeficiency virus 
highlights that TSPO is expressed in some but not all M1 (pathogenic) and M2 (immune-regulatory) phenotypes as well as intermediate microglia/macrophages $[169,170]$. Furthermore, a percentage of both TMEM $119^{+}$and $\mathrm{P} 2 \mathrm{RY} 12^{+}$cells, markers that represent homeostatic microglia, expresses TSPO in MS lesions indicating that TSPO PET is not merely a reflection of pathogenic microglia, although the trigger of TSPO upregulation in MS CNS is still unclear. In addition, in MS, TSPO is also expressed by T and B cells in the CNS and thus such cellular expression during disease must be considered in TSPO PET imaging.

\section{Neurodegenerative diseases}

An association between microglia activation, astrogliosis, and neuronal damage has been reported for several neurodegenerative diseases, e.g., AD, Parkinson's disease, and amyotrophic lateral sclerosis (ALS; motor neuron disease) [171]. As with MS, TSPO PET imaging is widely considered to reflect the pathogenic microglia in neurodegenerative diseases in vivo. Using postmortem brain tissues, several studies have used autoradiography to determine TSPO density in human brain tissues but few have examined the cellular distribution in detail (reviewed by [2]). Recently, a study using immunohistochemistry on AD human brain tissues revealed TSPO expression by microglia, astrocytes, endothelial cells, and vascular smooth muscle cells [172]. TSPO expression was not quantified by cell counts but rather by the amount of TSPO immunoreactivity. Although the authors reported a slight increase of TSPO immunoreactivity in the gray matter compared to healthy subjects, such expression was not associated with Braak stage, $A \beta$ plaques or neurofibrillary tangles or cortical thickness. While these authors showed TSPO expression by CD68 and IBA $1^{+}$microglia/macrophages, they did not examine expression in specific microglia phenotypes. Receptor density was not found to be increased in postmortem $\mathrm{AD}$ brain or in dementia with Lewy bodies (DLB) as investigated with quantitative autoradiography [173]. Interestingly, a significant decrease in receptor density or receptor binding was found in the substantia nigra of AD and DLB. No studies have been conducted to investigate the TSPO expression at the cellular level in other neurodegenerative diseases such as ALS, Huntington's disease, or spinocerebellar atrophy.

\section{Infections}

TSPO expression in the CNS of a few cases with HIV was reported to be similar to healthy human brain [167]. TSPO is reported in metabolic glia, a form of reactive astrocyte, and microglial cells. Tissues from HIV encephalitis (HIVE) cases revealed an increased expression of TSPO in lesioned areas. In cases where the origin of the infection was more unclear, there was a general increase of TSPO expression in activated microglia. HIVE brains showed perivascular $\mathrm{TSPO}^{+}$infiltrates as well as $\mathrm{TSPO}^{+}$microglial nodules and multinucleated giant cells. Studies to determine TSPO expression in infections of the central nervous systems have utilized PET imaging as reported for ZIKA [174] and herpes encephalitis animal models [175-177], as well as Creutzfeldt-Jakob disease patients [178], but have not yet investigated expression in postmortem tissues from humans.

\section{Neuropsychiatric disorders}

Several PET studies of TSPO as a marker of inflammation in psychiatric disorders have been performed but with differing outcomes. For example, PET studies in schizophrenia show different outcomes, either an increase, decrease, or no change compared to controls [179]. A recent review combining several meta-analyses [180-182] showed that overall patients with schizophrenia have lowered TSPO concentrations compared to healthy individuals [183]. On the other hand, in depression, TSPO seems to be upregulated mostly in the anterior cingulate and prefrontal cortex [184-186]. TSPO was overall lower in depression patients receiving SSRI medication compared to unmedicated patients [183]. For bipolar disorder, an increase of TSPO mRNA and protein together with inflammasome activation was found in peripheral blood monocytes [187]. However, while an increasing number of studies show TSPO changes in neuropsychiatric disorders with TSPO PET, there is a paucity of data using human CNS tissues to determine the cellular expression of TSPO in neuropsychiatric disorders to substantiate findings of TSPO PET.

\section{Stroke}

TSPO PET in brain trauma could aid in monitoring regenerative processes after stroke. Depending on the region and severity of the infarct, TSPO is expressed to differing degrees by surrounding microglia and hypertrophic astrocytes. In a subacute infarct in the cerebellar cortex, $\mathrm{TSPO}^{+}$microglia were found to be surrounding/ encapsulating Purkinje cells [167].

\section{Epilepsy}

PET studies show increased binding of TSPO ligand in both ipsilateral and contralateral regions in temporal lobe epilepsy (TLE) suggesting inflammation distant to the seizure foci. Examination of brain tissue surgically resected revealed high TSPO expression in microglia and neurons and low expression in astrocytes [188]. 


\section{FACS-RTT: a new technique to access to the cellular origin of TSPO}

To measure TSPO overexpression, some studies have used histological staining $[136,159]$. However, even if this technique presents the advantage of an intact cellular architecture of the tissue, there is not enough quantitative precision to determine the contribution of each cell population of the brain in TSPO signal. Similarly, histological approaches do not allow to assess an important parameter: does an alteration of TSPO in the tissue result from the modulation of the number of cells expressing TSPO? Or does each cell produce more TSPO?

To assess if the overexpression of TSPO is due to a cellular proliferation or an increased expression of TSPO in the cell, an innovative approach was recently developed [189]. This methodology combined the fluorescence-activated cell sorting (FACS) to isolate astrocytes, microglia, neurons, and endothelial cells and the radioligand-mediated labeling of TSPO (RTT, radioligand-treated tissues).

TSPO overexpression was studied in response to acute unilateral injection of lipopolysaccharide (LPS) or of ciliary neurotrophic factor (CNTF), in a rat model of AD and in the AD brain $[189,190]$. In all these pathological contexts, TSPO is overexpressed. However, the cellular origin of TSPO overexpression is context-dependent and cellular mechanisms leading to this increase are heterogenous (proliferation of the cell population and/or changes in TSPO expression by each single cell).

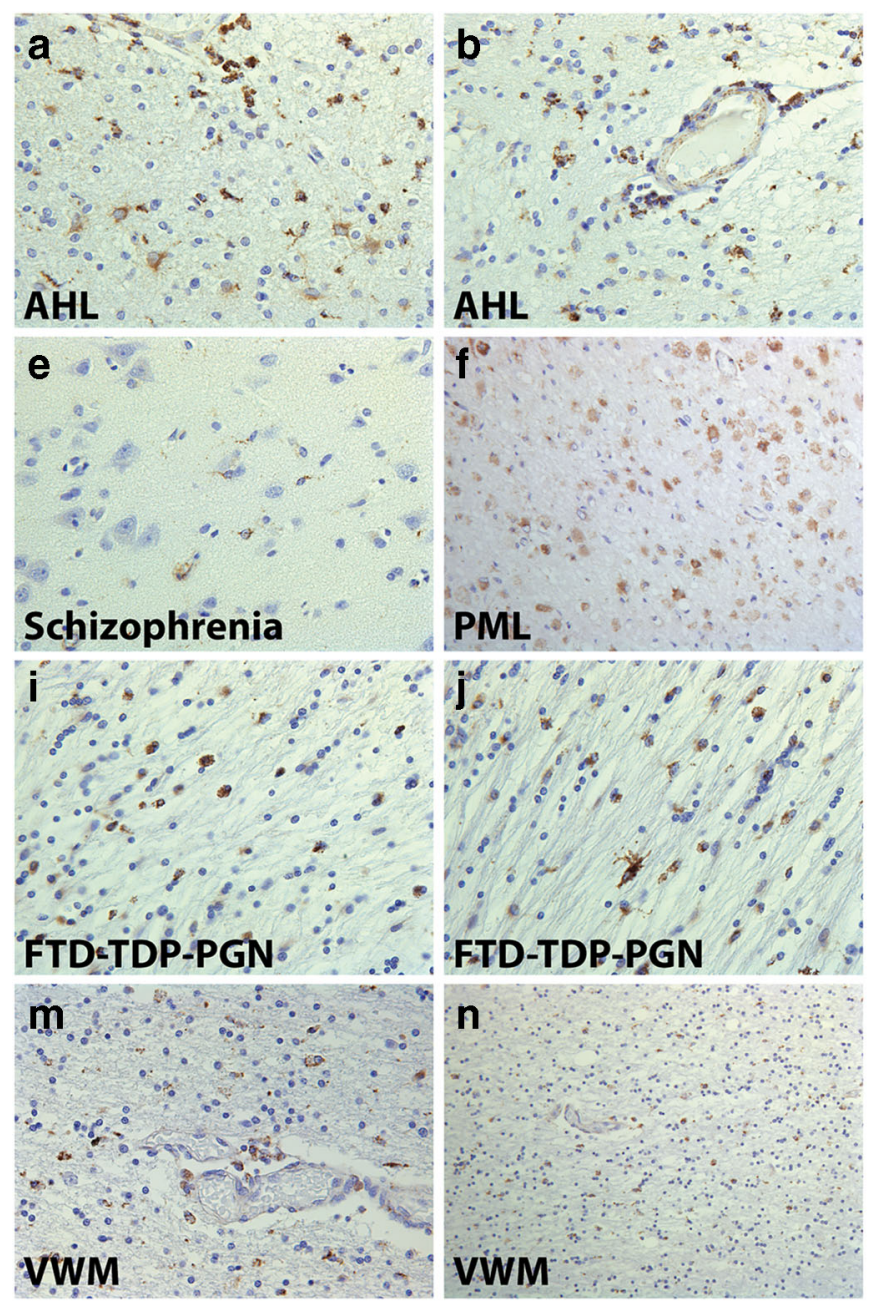

Fig. 1 Multiple cell origin of TSPO in the pathological human brain. Astrocytes and perivascular macrophages are positive for TSPO in acute hemorrhagic leukoencephalopathy (A, B). At the site of injury, acute stroke cells express TSPO in two separate cases (C, D). A schizophrenia patient with TSPO+ microglia and endothelial cells in the anterior cingulate cortex (E). Lesions in progressive multifocal leukoencephalopathy are abundant with TSPO in microglia, macrophages, and astrocytes in the white and gray matter $(F, G, H)$.

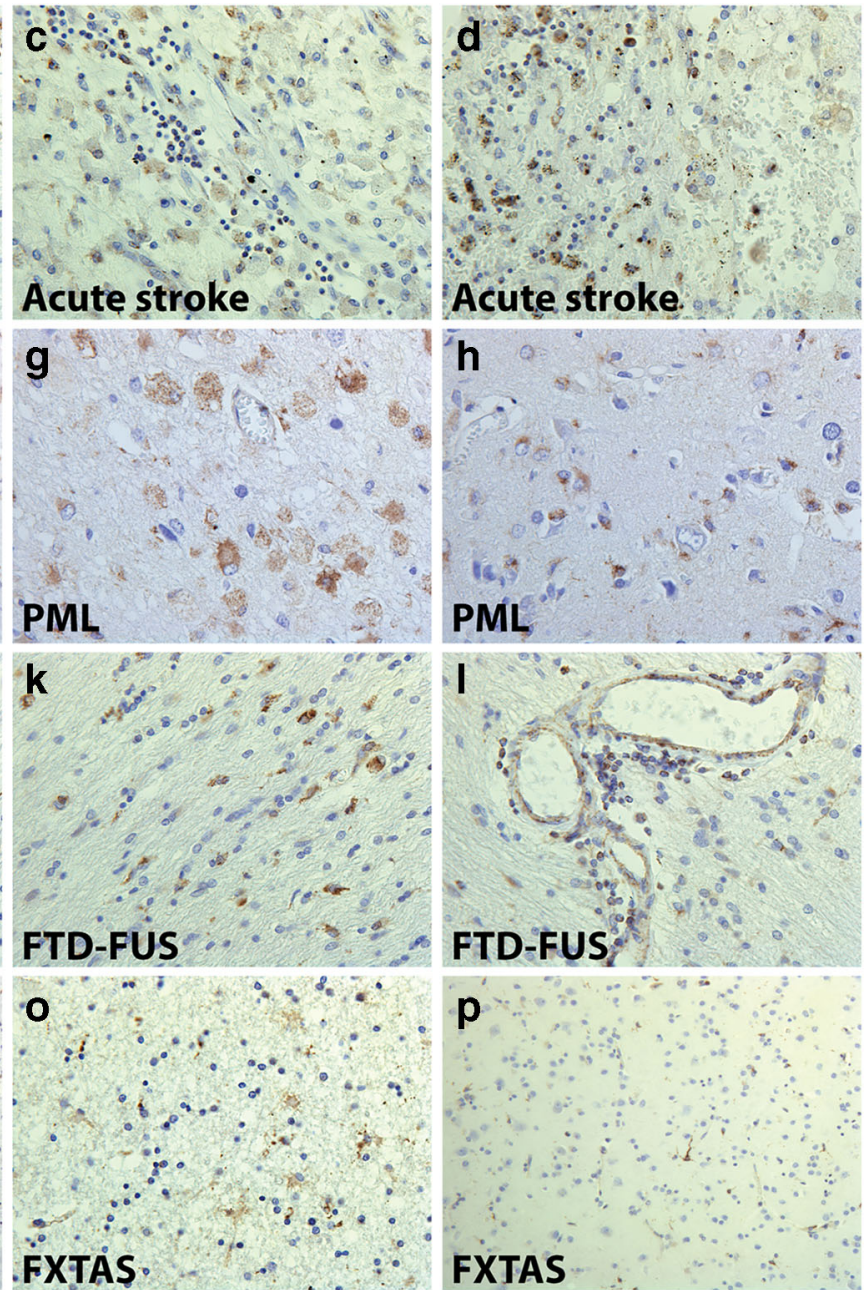

Patients with frontotemporal dementia with mutations for TDP, proganulin, and FUS have a macrophage-like cells expressing TSPO in the white matter and in perivascular spaces (I, J, K, L). Macrophages in vanishing white matter express TSPO throughout the white matter areas in the brain parenchyma (M, N). Fragile X-associated tremor/ataxia syndrome has TSPO+ astrocytes in the white matter and microglia in both white and gray matter $(\mathrm{O}, \mathrm{P})$ 
Furthermore, the involvement of endothelial TSPO binding in the overall TSPO signal is at the center of in vivo imaging interrogations. In the case of these models of inflammation, endothelial cells contributed to basal TSPO signal but not to its increase $[189,190]$. These results potentially answer a fundamental question in the domain of in vivo imaging of neuroinflammation, i.e., regarding the necessity to take the endothelial TSPO signal into account when quantifying TSPO in vivo using PET. Still, it is important to keep in mind that endothelial cells may contribute to TSPO signal in other conditions. Overall, these results confirm the complexity of TSPO and show the necessity to validate their cellular origin in each pathological context before quantifying and interpreting the in vivo imaging signal.

\section{Conclusion}

Since its identification, TSPO has been widely studied for its different roles in the periphery and more recently within the CNS itself. Its cellular origin demonstrated in the brain in microglia, although it is clear that other cell types also express TSPO and its presence in astrocytes and endothelial cells is now well accepted (Fig. 1). The cellular origin of TSPO alterations likely not only depends on the pathology but also on the developmental stage and mode of cell activation. Monitoring of TSPO levels is now widely used as a marker of inflammation, but research still needs to better characterize the means and cells involved. In this sense, it has recently been reported that the expression of TSPO concerns not only the proinflammatory types of microglia but also the antiinflammatory subtypes. Future studies should also reveal the therapeutic potential of a change in its levels.

Acknowledgments The authors thank the MS Society of Great Britain and Northern Ireland. Authors K.C. and B.B.T. are supported by the Velux Foundation (project n. 1123). Author S.T. received support from the Swiss National Science Foundation (Early PostDoc.Mobility Scholarship, no. P2GEP3 191446), the Prof Dr Max Cloetta Foundation (Clinical Medicine Plus scholarship), and the Jean and Madeleine Vachoux Foundation. Author D.R.O. is supported by the MRC (MR/N008219/1). Author V.P. was supported by the John Stauffer Dean's Chair in Pharmaceutical Sciences (University of Southern California). This work was supported by the Swiss National Science Foundation (no. 320030-184713).

Funding information Open Access funding provided by Université de Genève.

Data availability Not applicable.

\section{Compliance with ethical standards}

Conflict of interest The authors declare that they have no conflict of interest.

Ethics approval Not applicable.
Consent to participate Not applicable.

Consent for publication Not applicable.

Code availability Not applicable.

Open Access This article is licensed under a Creative Commons Attribution 4.0 International License, which permits use, sharing, adaptation, distribution and reproduction in any medium or format, as long as you give appropriate credit to the original author(s) and the source, provide a link to the Creative Commons licence, and indicate if changes were made. The images or other third party material in this article are included in the article's Creative Commons licence, unless indicated otherwise in a credit line to the material. If material is not included in the article's Creative Commons licence and your intended use is not permitted by statutory regulation or exceeds the permitted use, you will need to obtain permission directly from the copyright holder. To view a copy of this licence, visit http://creativecommons.org/licenses/by/4.0/.

\section{References}

1. Guilarte TR. TSPO in diverse CNS pathologies and psychiatric disease: a critical review and a way forward. Pharmacol Ther. 2019;194:44-58. https://doi.org/10.1016/j.pharmthera.2018.09. 003.

2. Guilarte TR. TSPO in diverse CNS pathologies and psychiatric disease: a critical review and a way forward. Pharmacol Ther. 2018. https://doi.org/10.1016/j.pharmthera.2018.09.003.

3. Venneti S, Lopresti BJ, Wang G, Hamilton RL, Mathis CA, Klunk WE, et al. PK11195 labels activated microglia in Alzheimer's disease and in vivo in a mouse model using PET. Neurobiol Aging. 2009;30:1217-26. https://doi.org/10.1016/j. neurobiolaging.2007.11.005.

4. Gui Y, Marks JD, Das S, Hyman BT, Serrano-Pozo A. Characterization of the $18 \mathrm{kDa}$ translocator protein (TSPO) expression in post-mortem normal and Alzheimer's disease brains. Brain Pathol. 2020;30:151-64. https://doi.org/10.1111/bpa. 12763.

5. Kaunzner UW, Kang Y, Zhang S, Morris E, Yao Y, Pandya S, et al. Quantitative susceptibility mapping identifies inflammation in a subset of chronic multiple sclerosis lesions. Brain. 2019;142: 133-45. https://doi.org/10.1093/brain/awy296.

6. Maeda J, Zhang MR, Okauchi T, Ji B, Ono M, Hattori S, et al. In vivo positron emission tomographic imaging of glial responses to amyloid-beta and tau pathologies in mouse models of Alzheimer's disease and related disorders. J Neurosci. 2011;31: 4720-30. https://doi.org/10.1523/JNEUROSCI.3076-10.2011.

7. Nutma E, Stephenson JA, Gorter RP, de Bruin J, Boucherie DM, Donat CK, et al. A quantitative neuropathological assessment of translocator protein expression in multiple sclerosis. Brain. 2019. https://doi.org/10.1093/brain/awz287.

8. Ahmad R, Koole M, Evens N, Serdons K, Verbruggen A, Bormans $\mathrm{G}$, et al. Whole-body biodistribution and radiation dosimetry of the cannabinoid type 2 receptor ligand [11C]-NE40 in healthy subjects. Mol Imaging Biol. 2013;15:384-90. https://doi. org/10.1007/s11307-013-0626-y.

9. Attili B, Celen S, Ahamed M, Koole M, Haute CVD, Vanduffel W, et al. Preclinical evaluation of [(18) F]MA3: a CB(2) receptor agonist radiotracer for PET. Br J Pharmacol. 2019;176:1481-91. https://doi.org/10.1111/bph.14564.

10. Kumar JSD, Prabhakaran J, Molotkov A, Sattiraju A, Kim J, Doubrovin $M$, et al. Radiosynthesis and evaluation of 
[(18)F]FMTP, a COX-2 PET ligand. Pharmacol Rep. 2020;72: 1433-40. https://doi.org/10.1007/s43440-020-00124-z.

11. Shrestha S, Kim MJ, Eldridge M, Lehmann ML, Frankland M, Liow JS, et al. PET measurement of cyclooxygenase-2 using a novel radioligand: upregulation in primate neuroinflammation and first-in-human study. J Neuroinflammation. 2020;17:140. https://doi.org/10.1186/s12974-020-01804-6.

12. Hosoya T, Fukumoto D, Kakiuchi T, Nishiyama S, Yamamoto S, Ohba $\mathrm{H}$, et al. In vivo TSPO and cannabinoid receptor type 2 availability early in post-stroke neuroinflammation in rats: a positron emission tomography study. J Neuroinflammation. 2017;14: 69. https://doi.org/10.1186/s12974-017-0851-4.

13. Pottier G, Gómez-Vallejo V, Padro D, Boisgard R, Dollé F, Llop $\mathrm{J}$, et al. PET imaging of cannabinoid type 2 receptors with [(11)C]A-836339 did not evidence changes following neuroinflammation in rats. J Cereb Blood Flow Metab. 2017;37:116378. https://doi.org/10.1177/0271678×16685105.

14. Territo PR, Meyer JA, Peters JS, Riley AA, McCarthy BP, Gao M, et al. Characterization of (11)C-GSK1482160 for targeting the P2X7 receptor as a biomarker for neuroinflammation. J Nucl Med. 2017;58:458-65. https://doi.org/10.2967/jnumed.116. 181354.

15. Berdyyeva T, Xia C, Taylor N, He Y, Chen G, Huang C, et al. PET Imaging of the P2X7 ion channel with a novel tracer [(18)F]JNJ-64413739 in a rat model of neuroinflammation. Mol Imaging Biol. 2019;21:871-8. https://doi.org/10.1007/s11307018-01313-2.

16. Kolb HC, Barret O, Bhattacharya A, Chen G, Constantinescu C, Huang C, et al. Preclinical evaluation and nonhuman primate receptor occupancy study of (18)F-JNJ-64413739, a PET radioligand for P2X7 receptors. J Nucl Med. 2019;60:1154-9. https://doi.org/10.2967/jnumed.118.212696.

17. Liu H, Jin H, Yue X, Luo Z, Liu C, Rosenberg AJ, et al. PET imaging study of S1PR1 expression in a rat model of multiple sclerosis. Mol Imaging Biol. 2016;18:724-32. https://doi.org/10. 1007/s11307-016-0944-y.

18. Weng CC, Carlin S, Hou C, Metz T, Li S, Lee H, et al. Correlation analysis of [(18)F]ROStrace using ex vivo autoradiography and dihydroethidium fluorescent imaging in lipopolysaccharidetreated animals. Biochem Biophys Res Commun. 2019;516: 397-401. https://doi.org/10.1016/j.bbrc.2019.06.062.

19. Horti AG, Naik R, Foss CA, Minn I, Misheneva V, Du Y, et al. PET imaging of microglia by targeting macrophage colonystimulating factor 1 receptor (CSF1R). Proc Natl Acad Sci U S A. 2019;116:1686-91. https://doi.org/10.1073/pnas.1812155116.

20. Papadopoulos V, Baraldi M, Guilarte TR, Knudsen TB, Lacapere JJ, Lindemann P, et al. Translocator protein (18 kDa): new nomenclature for the peripheral-type benzodiazepine receptor based on its structure and molecular function. Trends Pharmacol Sci. 2006;27:402-9. https://doi.org/10.1016/j.tips.2006.06.005.

21. Rupprecht R, Papadopoulos V, Rammes G, Baghai TC, Fan J, Akula N, et al. Translocator protein (18 kDa) (TSPO) as a therapeutic target for neurological and psychiatric disorders. Nat Rev Drug Discov. 2010;9:971-88. https://doi.org/10.1038/nrd3295.

22. Veenman L, Papadopoulos V, Gavish M. Channel-like functions of the 18-kDa translocator protein (TSPO): regulation of apoptosis and steroidogenesis as part of the host-defense response. Curr Pharm Des. 2007;13:2385-405. https://doi.org/10.2174/ 138161207781368710.

23. Gavish M, Bachman I, Shoukrun R, Katz Y, Veenman L, Weisinger G, et al. Enigma of the peripheral benzodiazepine receptor. Pharmacol Rev. 1999;51:629-50.

24. Austin CJ, Kahlert J, Kassiou M, Rendina LM. The translocator protein (TSPO): a novel target for cancer chemotherapy. Int $\mathrm{J}$ Biochem Cell Biol. 2013;45:1212-6. https://doi.org/10.1016/j. biocel.2013.03.004.
25. Batarseh A, Papadopoulos V. Regulation of translocator protein $18 \mathrm{kDa}$ (TSPO) expression in health and disease states. Mol Cell Endocrinol. 2010;327(1-12). https://doi.org/10.1016/j.mce.2010. 06.013 .

26. Caballero B, Veenman L, Gavish M. Role of mitochondrial translocator protein $(18 \mathrm{kDa})$ on mitochondrial-related cell death processes. Recent Pat Endocr Metab Immune Drug Discovery. 2013;7:86-101. https://doi.org/10.2174/1872214811307020002.

27. Papadopoulos V. Peripheral-type benzodiazepine/diazepam binding inhibitor receptor: biological role in steroidogenic cell function. Endocr Rev. 1993;14:222-40. https://doi.org/10.1210/edrv14-2-222.

28. Veenman L, Gavish M. The peripheral-type benzodiazepine receptor and the cardiovascular system. Implications for drug development. Pharmacol Ther. 2006;110:503-24. https://doi.org/10. 1016/j.pharmthera.2005.09.007.

29. Galiegue S, Casellas P, Kramar A, Tinel N, Simony-Lafontaine J. Immunohistochemical assessment of the peripheral benzodiazepine receptor in breast cancer and its relationship with survival. Clin Cancer Res. 2004;10:2058-64. https://doi.org/10.1158/10780432.ccr-03-0988.

30. Tonon MC, Vaudry H, Chuquet J, Guillebaud F, Fan J, Masmoudi-Kouki O, et al. Endozepines and their receptors: structure, functions and pathophysiological significance. Pharmacol Ther. 2019:107386. https://doi.org/10.1016/j.pharmthera.2019. 06.008 .

31. Chen MK, Guilarte TR. Translocator protein $18 \mathrm{kDa}$ (TSPO): molecular sensor of brain injury and repair. Pharmacol Ther. 2008;118:1-17. https://doi.org/10.1016/j.pharmthera.2007.12. 004.

32. Taliani S, Da Settimo F, Da Pozzo E, Chelli B, Martini C. Translocator protein ligands as promising therapeutic tools for anxiety disorders. Curr Med Chem. 2009;16:3359-80. https:// doi.org/10.2174/092986709789057653.

33. Liu GJ, Middleton RJ, Hatty CR, Kam WW, Chan R, Pham T, et al. The $18 \mathrm{kDa}$ translocator protein, microglia and neuroinflammation. Brain Pathol. 2014;24:631-53. https://doi.org/10.1111/ bpa.12196.

34. Wang HJ, Fan J, Papadopoulos V. Translocator protein (Tspo) gene promoter-driven green fluorescent protein synthesis in transgenic mice: an in vivo model to study Tspo transcription. Cell Tissue Res. 2012;350:261-75. https://doi.org/10.1007/s00441012-1478-5.

35. Bribes E, Carriere D, Goubet C, Galiegue S, Casellas P, SimonyLafontaine J. Immunohistochemical assessment of the peripheral benzodiazepine receptor in human tissues. J Histochem Cytochem. 2004;52:19-28. https://doi.org/10.1177/ 002215540405200103.

36. Katz Y, Ben-Baruch G, Kloog Y, Menczer J, Gavish M. Increased density of peripheral benzodiazepine-binding sites in ovarian carcinomas as compared with benign ovarian tumours and normal ovaries. Clin Sci (Lond). 1990;78:155-8. https://doi.org/10. 1042/cs0780155.

37. Bhoola NH, Mbita Z, Hull R, Dlamini Z. Translocator protein (TSPO) as a potential biomarker in human cancers. Int J Mol Sci. 2018;19. https://doi.org/10.3390/ijms19082176.

38. Han Z, Slack RS, Li W, Papadopoulos V. Expression of peripheral benzodiazepine receptor (PBR) in human tumors: relationship to breast, colorectal, and prostate tumor progression. J Recept Signal Transduct Res. 2003;23:225-38. https://doi.org/10.1081/rrs120025210.

39. Batarseh A, Barlow KD, Martinez-Arguelles DB, Papadopoulos V. Functional characterization of the human translocator protein $(18 \mathrm{kDa})$ gene promoter in human breast cancer cell lines. Biochim Biophys Acta. 2012;1819:38-56. https://doi.org/10. 1016/j.bbagrm.2011.09.001. 
40. Hardwick M, Cavalli LR, Barlow KD, Haddad BR, Papadopoulos V. Peripheral-type benzodiazepine receptor (PBR) gene amplification in MDA-MB-231 aggressive breast cancer cells. Cancer Genet Cytogenet. 2002;139:48-51. https://doi.org/10.1016/ s0165-4608(02)00604-0.

41. Anholt RR, Pedersen PL, De Souza EB, Snyder SH. The peripheral-type benzodiazepine receptor. Localization to the mitochondrial outer membrane. J Biol Chem. 1986;261:576-83.

42. Garnier M, Boujrad N, Oke BO, Brown AS, Riond J, Ferrara P, et al. Diazepam binding inhibitor is a paracrine/autocrine regulator of Leydig cell proliferation and steroidogenesis: action via peripheral-type benzodiazepine receptor and independent mechanisms. Endocrinology. 1993;132:444-58. https://doi.org/10.1210/ endo.132.1.8380386.

43. Hardwick M, Fertikh D, Culty M, Li H, Vidic B, Papadopoulos V. Peripheral-type benzodiazepine receptor (PBR) in human breast cancer: correlation of breast cancer cell aggressive phenotype with PBR expression, nuclear localization, and PBR-mediated cell proliferation and nuclear transport of cholesterol. Cancer Res. 1999;59:831-42.

44. Doble A, Ferris O, Burgevin MC, Menager J, Uzan A, Dubroeucq $\mathrm{MC}$, et al. Photoaffinity labeling of peripheral-type benzodiazepine-binding sites. Mol Pharmacol. 1987;31:42-9.

45. Antkiewicz-Michaluk L, Mukhin AG, Guidotti A, Krueger KE. Purification and characterization of a protein associated with peripheral-type benzodiazepine binding sites. J Biol Chem. 1988;263:17317-21.

46. Riond J, Vita N, Le Fur G, Ferrara P. Characterization of a peripheral-type benzodiazepine-binding site in the mitochondria of Chinese hamster ovary cells. FEBS Lett. 1989;245:238-44. https://doi.org/10.1016/0014-5793(89)80229-7.

47. Sprengel R, Werner P, Seeburg PH, Mukhin AG, Santi MR, Grayson DR, et al. Molecular cloning and expression of cDNA encoding a peripheral-type benzodiazepine receptor. J Biol Chem. 1989;264:20415-21.

48. Riond J, Mattei MG, Kaghad M, Dumont X, Guillemot JC, Le Fur $\mathrm{G}$, et al. Molecular cloning and chromosomal localization of a human peripheral-type benzodiazepine receptor. Eur J Biochem. 1991;195:305-11. https://doi.org/10.1111/j.1432-1033.1991. tb15707.x.

49. Chang YJ, McCabe RT, Rennert H, Budarf ML, Sayegh R, Emanuel BS, et al. The human "peripheral-type" benzodiazepine receptor: regional mapping of the gene and characterization of the receptor expressed from cDNA. DNA Cell Biol. 1992;11:471-80. https://doi.org/10.1089/dna.1992.11.471.

50. Parola AL, Stump DG, Pepperl DJ, Krueger KE, Regan JW, Laird HE 2nd. Cloning and expression of a pharmacologically unique bovine peripheral-type benzodiazepine receptor isoquinoline binding protein. J Biol Chem. 1991;266:14082-7.

51. Garnier M, Dimchev AB, Boujrad N, Price JM, Musto NA, Papadopoulos V. In vitro reconstitution of a functional peripheral-type benzodiazepine receptor from mouse Leydig tumor cells. Mol Pharmacol. 1994;45:201-11.

52. McEnery MW, Snowman AM, Trifiletti RR, Snyder SH. Isolation of the mitochondrial benzodiazepine receptor: association with the voltage-dependent anion channel and the adenine nucleotide carrier. Proc Natl Acad Sci U S A. 1992;89:3170-4. https://doi.org/ 10.1073/pnas.89.8.3170.

53. Levitt D. Gramicidin, VDAC, porin and perforin channels. Curr Opin Cell Biol. 1990;2:689-94. https://doi.org/10.1016/09550674(90)90112-r.

54. Le Fur G, Vaucher N, Perrier ML, Flamier A, Benavides J, Renault $\mathrm{C}$, et al. Differentiation between two ligands for peripheral benzodiazepine binding sites, $[3 \mathrm{H}] \mathrm{RO} 5-4864$ and $[3 \mathrm{H}] \mathrm{PK}$ 11195, by thermodynamic studies. Life Sci. 1983;33:449-57. https://doi.org/10.1016/0024-3205(83)90794-4.
55. Rone MB, Liu J, Blonder J, Ye X, Veenstra TD, Young JC, et al. Targeting and insertion of the cholesterol-binding translocator protein into the outer mitochondrial membrane. Biochemistry. 2009;48:6909-20. https://doi.org/10.1021/bi900854z.

56. Lacapere JJ, Papadopoulos V. Peripheral-type benzodiazepine receptor: structure and function of a cholesterol-binding protein in steroid and bile acid biosynthesis. Steroids. 2003;68:569-85. https://doi.org/10.1016/s0039-128x(03)00101-6.

57. Li F, Liu J, Liu N, Kuhn LA, Garavito RM, Ferguson-Miller S. Translocator protein $18 \mathrm{kDa}$ (TSPO): an old protein with new functions? Biochemistry. 2016;55:2821-31. https://doi.org/10. 1021/acs.biochem.6b00142.

58. Rone MB, Midzak AS, Issop L, Rammouz G, Jagannathan S, Fan $\mathrm{J}$, et al. Identification of a dynamic mitochondrial protein complex driving cholesterol import, trafficking, and metabolism to steroid hormones. Mol Endocrinol. 2012;26:1868-82. https://doi.org/10. 1210/me.2012-1159.

59. Gatliff J, East D, Crosby J, Abeti R, Harvey R, Craigen W, et al. TSPO interacts with VDAC1 and triggers a ROS-mediated inhibition of mitochondrial quality control. Autophagy. 2014;10: 2279-96. https://doi.org/10.4161/15548627.2014.991665.

60. Issop L, Rone MB, Papadopoulos V. Organelle plasticity and interactions in cholesterol transport and steroid biosynthesis. Mol Cell Endocrinol. 2013;371:34 46. https://doi.org/10.1016/j. mce.2012.12.003.

61. Aghazadeh Y, Zirkin BR, Papadopoulos V. Pharmacological regulation of the cholesterol transport machinery in steroidogenic cells of the testis. Vitam Horm. 2015;98:189-227. https://doi. org/10.1016/bs.vh.2014.12.006.

62. Oke BO, Suarez-Quian CA, Riond J, Ferrara P, Papadopoulos V. Cell surface localization of the peripheral-type benzodiazepine receptor (PBR) in adrenal cortex. Mol Cell Endocrinol. 1992;87: R1-6. https://doi.org/10.1016/0303-7207(92)90248-5.

63. Hirsch JD, Beyer CF, Malkowitz L, Beer B, Blume AJ. Mitochondrial benzodiazepine receptors mediate inhibition of mitochondrial respiratory control. Mol Pharmacol. 1989;35:157-63.

64. Larcher JC, Vayssiere JL, Le Marquer FJ, Cordeau LR, Keane PE, Bachy A, et al. Effects of peripheral benzodiazepines upon the O2 consumption of neuroblastoma cells. Eur J Pharmacol. 1989;161: 197-202. https://doi.org/10.1016/0014-2999(89)90843-1.

65. Lejri I, Grimm A, Halle F, Abarghaz M, Klein C, Maitre M, et al. TSPO ligands boost mitochondrial function and pregnenolone synthesis. J Alzheimers Dis. 2019;72:1045-58. https://doi.org/ 10.3233/JAD-190127.

66. Papadopoulos V, Aghazadeh Y, Fan J, Campioli E, Zirkin B, Midzak A. Translocator protein-mediated pharmacology of cholesterol transport and steroidogenesis. Mol Cell Endocrinol. 2015;408:90-8. https://doi.org/10.1016/j.mce.2015.03.014.

67. Papadopoulos V, Fan J, Zirkin B. Translocator protein (18 kDa): an update on its function in steroidogenesis. J Neuroendocrinol. 2018;30. https://doi.org/10.1111/jne.12500.

68. Costa E, Auta J, Guidotti A, Korneyev A, Romeo E. The pharmacology of neurosteroidogenesis. J Steroid Biochem Mol Biol. 1994;49:385-9. https://doi.org/10.1016/0960-0760(94)90284-4.

69. Papadopoulos V, Guarneri P, Kreuger KE, Guidotti A, Costa E. Pregnenolone biosynthesis in C6-2B glioma cell mitochondria: regulation by a mitochondrial diazepam binding inhibitor receptor. Proc Natl Acad Sci U S A. 1992;89:5113-7. https://doi.org/ 10.1073/pnas.89.11.5113.

70. Arbo BD, Benetti F, Garcia-Segura LM, Ribeiro MF. Therapeutic actions of translocator protein $(18 \mathrm{kDa})$ ligands in experimental models of psychiatric disorders and neurodegenerative diseases. J Steroid Biochem Mol Biol. 2015;154:68-74. https://doi.org/10. 1016/j.jsbmb.2015.07.007.

71. Porcu P, Barron AM, Frye CA, Walf AA, Yang SY, He XY, et al. Neurosteroidogenesis today: novel targets for neuroactive steroid 
synthesis and action and their relevance for translational research. J Neuroendocrinol. 2016;28:12351. https://doi.org/10.1111/jne. 12351.

72. Falchi AM, Battetta B, Sanna F, Piludu M, Sogos V, Serra M, et al. Intracellular cholesterol changes induced by translocator protein $(18 \mathrm{kDa})$ TSPO/PBR ligands. Neuropharmacology. 2007;53:318-29. https://doi.org/10.1016/j.neuropharm.2007.05. 016.

73. Chung JY, Chen H, Papadopoulos V, Zirkin B. Cholesterol accumulation, lipid droplet formation, and steroid production in Leydig cells: role of translocator protein $(18-\mathrm{kDa})$. Andrology. 2019. https://doi.org/10.1111/andr.12733.

74. Lacapere JJ, Duma L, Finet S, Kassiou M, Papadopoulos V. Insight into the structural features of TSPO: implications for drug development. Trends Pharmacol Sci. 2020;41:110-22. https://doi. org/10.1016/j.tips.2019.11.005.

75. Costa B, Da Pozzo E, Giacomelli C, Barresi E, Taliani S, Da Settimo F, et al. TSPO ligand residence time: a new parameter to predict compound neurosteroidogenic efficacy. Sci Rep. 2016;6:18164. https://doi.org/10.1038/srep18164.

76. Costa B, Cavallini C, Da Pozzo E, Taliani S, Da Settimo F, Martini C. The anxiolytic etifoxine binds to TSPO Ro5-4864 binding site with long residence time showing a high neurosteroidogenic activity. ACS Chem Neurosci. 2017;8:144854. https://doi.org/10.1021/acschemneuro.7b00027.

77. Hatty CR, Banati RB. Protein-ligand and membrane-ligand interactions in pharmacology: the case of the translocator protein (TSPO). Pharmacol Res. 2015;100:58-63. https://doi.org/10. 1016/j.phrs.2015.07.029.

78. Kletsas D, Li W, Han Z, Papadopoulos V. Peripheral-type benzodiazepine receptor (PBR) and PBR drug ligands in fibroblast and fibrosarcoma cell proliferation: role of ERK, c-Jun and ligandactivated PBR-independent pathways. Biochem Pharmacol. 2004;67:1927-32. https://doi.org/10.1016/j.bcp.2004.01.021.

79. Bader S, Wolf L, Milenkovic VM, Gruber M, Nothdurfter C, Rupprecht R, et al. Differential effects of TSPO ligands on mitochondrial function in mouse microglia cells. Psychoneuroendocrinology. 2019;106:65-76. https://doi.org/10. 1016/j.psyneuen.2019.03.029.

80. Veenman L, Shandalov Y, Gavish M. VDAC activation by the $18 \mathrm{kDa}$ translocator protein (TSPO), implications for apoptosis. J Bioenerg Biomembr. 2008;40:199-205. https://doi.org/10.1007/ s10863-008-9142-1.

81. Veenman L, Alten J, Linnemannstons K, Shandalov Y, Zeno S, Lakomek M, et al. Potential involvement of F0F1-ATP(synth)ase and reactive oxygen species in apoptosis induction by the antineoplastic agent erucylphosphohomocholine in glioblastoma cell lines : a mechanism for induction of apoptosis via the $18 \mathrm{kDa}$ mitochondrial translocator protein. Apoptosis. 2010;15:753-68. https://doi.org/10.1007/s10495-010-0460-5.

82. Veenman L, Gavish M. The role of $18 \mathrm{kDa}$ mitochondrial translocator protein (TSPO) in programmed cell death, and effects of steroids on TSPO expression. Curr Mol Med. 2012;12:398 412. https://doi.org/10.2174/1566524011207040398.

83. Azarashvili T, Grachev D, Krestinina O, Evtodienko Y, Yurkov I, Papadopoulos V, et al. The peripheral-type benzodiazepine receptor is involved in control of $\mathrm{Ca} 2+$-induced permeability transition pore opening in rat brain mitochondria. Cell Calcium. 2007;42: 27-39. https://doi.org/10.1016/j.ceca.2006.11.004.

84. Zulian A, Sileikyte J, Petronilli V, Bova S, Dabbeni-Sala F, Cargnelli $\mathrm{G}$, et al. The translocator protein (peripheral benzodiazepine receptor) mediates rat-selective activation of the mitochondrial permeability transition by norbormide. Biochim Biophys Acta. 2011;1807:1600-5. https://doi.org/10.1016/j.bbabio.2011. 08.007 .
85. Galiegue S, Tinel N, Casellas P. The peripheral benzodiazepine receptor: a promising therapeutic drug target. Curr Med Chem. 2003;10:1563-72. https://doi.org/10.2174/0929867033457223.

86. Katz Y, Eitan A, Gavish M. Increase in peripheral benzodiazepine binding sites in colonic adenocarcinoma. Oncology. 1990;47: 139-42. https://doi.org/10.1159/000226806.

87. Lacapere JJ, Duma L, Finet S, Kassiou M, Papadopoulos V. Insight into the structural features of TSPO: implications for drug development. Trends Pharmacol Sci. 2019. https://doi.org/10. 1016/j.tips.2019.11.005.

88. Li H, Papadopoulos V. Peripheral-type benzodiazepine receptor function in cholesterol transport. Identification of a putative cholesterol recognition/interaction amino acid sequence and consensus pattern. Endocrinology. 1998;139:4991-7. https://doi.org/10. 1210/endo.139.12.6390.

89. Li H, Yao Z, Degenhardt B, Teper G, Papadopoulos V. Cholesterol binding at the cholesterol recognition/interaction amino acid consensus (CRAC) of the peripheral-type benzodiazepine receptor and inhibition of steroidogenesis by an HIV TAT-CRAC peptide. Proc Natl Acad Sci U S A. 2001;98:1267-72. https://doi. org/10.1073/pnas.031461598.

90. Jamin N, Neumann JM, Ostuni MA, Vu TK, Yao ZX, Murail S, et al. Characterization of the cholesterol recognition amino acid consensus sequence of the peripheral-type benzodiazepine receptor. Mol Endocrinol. 2005;19:588-94. https://doi.org/10.1210/me. 2004-0308.

91. Jaipuria G, Leonov A, Giller K, Vasa SK, Jaremko L, Jaremko M, et al. Cholesterol-mediated allosteric regulation of the mitochondrial translocator protein structure. Nat Commun. 2017;8:14893. https://doi.org/10.1038/ncomms14893.

92. Jaremko L, Jaremko M, Giller K, Becker S, Zweckstetter M. Structure of the mitochondrial translocator protein in complex with a diagnostic ligand. Science. 2014;343:1363-6. https://doi. org/10.1126/science.1248725.

93. Li F, Liu J, Zheng Y, Garavito RM, Ferguson-Miller S. Protein structure. Crystal structures of translocator protein (TSPO) and mutant mimic of a human polymorphism. Science. 2015;347: 555-8. https://doi.org/10.1126/science.1260590.

94. Korkhov VM, Sachse C, Short JM, Tate CG. Three-dimensional structure of TspO by electron cryomicroscopy of helical crystals. Structure. 2010;18:677-87. https://doi.org/10.1016/j.str.2010.03. 001.

95. Iatmanen-Harbi S, Senicourt L, Papadopoulos V, Lequin O, Lacapere JJ. Characterization of the high-affinity drug ligand binding site of mouse recombinant TSPO. Int J Mol Sci. 2019;20. https://doi.org/10.3390/ijms20061444.

96. Guo Y, Kalathur RC, Liu Q, Kloss B, Bruni R, Ginter C, et al. Protein structure. Structure and activity of tryptophan-rich TSPO proteins. Science. 2015;347:551-5. https://doi.org/10.1126/ science.aaa 1534

97. Jaipuria G, Giller K, Leonov A, Becker S, Zweckstetter M. Insights into cholesterol/membrane protein interactions using paramagnetic solid-state NMR. Chemistry. 2018;24:17606-11. https://doi.org/10.1002/chem.201804550.

98. Taylor JM, Allen AM, Graham A. Targeting mitochondrial $18 \mathrm{kDa}$ translocator protein (TSPO) regulates macrophage cholesterol efflux and lipid phenotype. Clin Sci (Lond). 2014;127:60313. https://doi.org/10.1042/CS20140047.

99. Biswas L, Zhou X, Dhillon B, Graham A, Shu X. Retinal pigment epithelium cholesterol efflux mediated by the $18 \mathrm{kDa}$ translocator protein, TSPO, a potential target for treating age-related macular degeneration. Hum Mol Genet. 2017;26:4327-39. https://doi.org/ $10.1093 / \mathrm{hmg} / \mathrm{dd} \times 319$.

100. Elustondo P, Martin LA, Karten B. Mitochondrial cholesterol import. Biochim Biophys Acta Mol Cell Biol Lipids. 2017;1862:90101. https://doi.org/10.1016/j.bbalip.2016.08.012. 
101. Rone MB, Fan J, Papadopoulos V. Cholesterol transport in steroid biosynthesis: role of protein-protein interactions and implications in disease states. Biochim Biophys Acta. 2009;1791:646-58. https://doi.org/10.1016/j.bbalip.2009.03.001.

102. Mari M, Morales A, Colell A, Garcia-Ruiz C, Fernandez-Checa JC. Mitochondrial glutathione, a key survival antioxidant. Antioxid Redox Signal. 2009;11:2685-700. https://doi.org/10. 1089/ARS.2009.2695.

103. Gatliff J, Campanella M. TSPO is a REDOX regulator of cell mitophagy. Biochem Soc Trans. 2015;43:543-52. https://doi. org/10.1042/BST20150037.

104. Gatliff J, East DA, Singh A, Alvarez MS, Frison M, Matic I, et al. A role for TSPO in mitochondrial $\mathrm{Ca}(2+)$ homeostasis and redox stress signaling. Cell Death Dis. 2017;8:e2896. https://doi.org/10. 1038/cddis.2017.186.

105. Sileikyte J, Blachly-Dyson E, Sewell R, Carpi A, Menabo R, Di Lisa F, et al. Regulation of the mitochondrial permeability transition pore by the outer membrane does not involve the peripheral benzodiazepine receptor (translocator protein of $18 \mathrm{kDa}$ (TSPO)). J Biol Chem. 2014;289:13769-81. https://doi.org/10.1074/jbc. M114.549634.

106. Morohaku K, Pelton SH, Daugherty DJ, Butler WR, Deng W, Selvaraj V. Translocator protein/peripheral benzodiazepine receptor is not required for steroid hormone biosynthesis. Endocrinology. 2014;155:89-97. https://doi.org/10.1210/en. 2013-1556.

107. Tu LN, Morohaku K, Manna PR, Pelton SH, Butler WR, Stocco $\mathrm{DM}$, et al. Peripheral benzodiazepine receptor/translocator protein global knock-out mice are viable with no effects on steroid hormone biosynthesis. J Biol Chem. 2014;289:27444-54. https://doi. org/10.1074/jbc.M114.578286.

108. Banati RB, Middleton RJ, Chan R, Hatty CR, Kam WW, Quin C, et al. Positron emission tomography and functional characterization of a complete PBR/TSPO knockout. Nat Commun. 2014;5: 5452. https://doi.org/10.1038/ncomms6452.

109. Fan J, Campioli E, Midzak A, Culty M, Papadopoulos V. Conditional steroidogenic cell-targeted deletion of TSPO unveils a crucial role in viability and hormone-dependent steroid formation. Proc Natl Acad Sci U S A. 2015;112:7261-6. https://doi.org/ 10.1073/pnas.1502670112.

110. Owen DR, Fan J, Campioli E, Venugopal S, Midzak A, Daly E, et al. TSPO mutations in rats and a human polymorphism impair the rate of steroid synthesis. Biochem J. 2017;474:3985-99. https://doi.org/10.1042/BCJ20170648.

111. Barron AM, Ji B, Kito S, Suhara T, Higuchi M. Steroidogenic abnormalities in translocator protein knockout mice and significance in the aging male. Biochem J. 2018;475:75-85. https://doi. org/10.1042/BCJ20170645.

112. Barron AM, Higuchi M, Hattori S, Kito S, Suhara T, Ji B. Regulation of anxiety and depression by mitochondrial translocator protein-mediated steroidogenesis: the role of neurons. Mol Neurobiol. 2020. https://doi.org/10.1007/s12035-02002136-5.

113. Hauet T, Yao ZX, Bose HS, Wall CT, Han Z, Li W, et al. Peripheral-type benzodiazepine receptor-mediated action of steroidogenic acute regulatory protein on cholesterol entry into Leydig cell mitochondria. Mol Endocrinol. 2005;19:540-54. https://doi.org/10.1210/me.2004-0307.

114. Kelly-Hershkovitz E, Weizman R, Spanier I, Leschiner S, Lahav $\mathrm{M}$, Weisinger $\mathrm{G}$, et al. Effects of peripheral-type benzodiazepine receptor antisense knockout on MA-10 Leydig cell proliferation and steroidogenesis. J Biol Chem. 1998;273:5478-83. https://doi. org/10.1074/jbc.273.10.5478.

115. Tu LN, Zhao AH, Stocco DM, Selvaraj V. PK11195 effect on steroidogenesis is not mediated through the translocator protein
(TSPO). Endocrinology. 2015;156:1033-9. https://doi.org/10. 1210/en.2014-1707.

116. Fan J, Wang K, Zirkin B, Papadopoulos V. CRISPR/Cas9 mediated Tspo gene mutations lead to reduced mitochondrial membrane potential and steroid formation in MA-10 mouse tumor Leydig cells. Endocrinology. 2018;159:1130-46. https://doi.org/ 10.1210/en.2017-03065.

117. Verma A, Facchina SL, Hirsch DJ, Song SY, Dillahey LF, Williams JR, et al. Photodynamic tumor therapy: mitochondrial benzodiazepine receptors as a therapeutic target. Mol Med. 1998;4:40-5.

118. Verma A, Nye JS, Snyder SH. Porphyrins are endogenous ligands for the mitochondrial (peripheral-type) benzodiazepine receptor. Proc Natl Acad Sci U S A. 1987;84:2256-60. https://doi.org/10. 1073/pnas.84.8.2256.

119. Taketani S, Kohno H, Furukawa T, Tokunaga R. Involvement of peripheral-type benzodiazepine receptors in the intracellular transport of heme and porphyrins. J Biochem. 1995;117:875-80. https://doi.org/10.1093/oxfordjournals.jbchem.a124790.

120. Zhao AH, Tu LN, Mukai C, Sirivelu MP, Pillai VV, Morohaku K, et al. Mitochondrial translocator protein (TSPO) function is not essential for heme biosynthesis. J Biol Chem. 2016;291:1591603. https://doi.org/10.1074/jbc.M115.686360.

121. Milenkovic VM, Slim D, Bader S, Koch V, Heinl ES, AlvarezCarbonell D, et al. CRISPR-Cas9 mediated TSPO gene knockout alters respiration and cellular metabolism in human primary microglia cells. Int J Mol Sci. 2019;20. https://doi.org/10.3390/ ijms20133359.

122. Urbani A, Giorgio V, Carrer A, Franchin C, Arrigoni G, Jiko C, et al. Purified F-ATP synthase forms a $\mathrm{Ca}(2+)$-dependent highconductance channel matching the mitochondrial permeability transition pore. Nat Commun. 2019;10:4341. https://doi.org/10. 1038/s41467-019-12331-1.

123. Owen DR, Yeo AJ, Gunn RN, Song K, Wadsworth G, Lewis A, et al. An 18-kDa translocator protein (TSPO) polymorphism explains differences in binding affinity of the PET radioligand PBR28. J Cereb Blood Flow Metab. 2012;32:1-5. https://doi. org/10.1038/jcbfm.2011.147.

124. Costa B, Pini S, Martini C, Abelli M, Gabelloni P, Landi S, et al. Ala147Thr substitution in translocator protein is associated with adult separation anxiety in patients with depression. Psychiatr Genet. 2009;19:110-1. https://doi.org/10.1097/YPG. 0b013e32832080f6.

125. Nakamura K, Yamada K, Iwayama Y, Toyota T, Furukawa A, Takimoto T, et al. Evidence that variation in the peripheral benzodiazepine receptor (PBR) gene influences susceptibility to panic disorder. Am J Med Genet B Neuropsychiatr Genet. 2006;141B: 222-6. https://doi.org/10.1002/ajmg.b.30211.

126. Colasanti A, Owen DR, Grozeva D, Rabiner EA, Matthews PM, Craddock N, et al. Bipolar disorder is associated with the rs6971 polymorphism in the gene encoding $18 \mathrm{kDa}$ translocator protein (TSPO). Psychoneuroendocrinology. 2013;38:2826-9. https:// doi.org/10.1016/j.psyneuen.2013.07.007.

127. Da Pozzo E, Costa B, Martini C. Translocator protein (TSPO) and neurosteroids: implications in psychiatric disorders. Curr Mol Med. 2012;12:426-42. https://doi.org/10.2174/ 156652412800163451 .

128. Rupprecht R, Rammes G, Eser D, Baghai TC, Schule C, Nothdurfter C, et al. Translocator protein $(18 \mathrm{kD})$ as target for anxiolytics without benzodiazepine-like side effects. Science. 2009;325:490-3. https://doi.org/10.1126/science.1175055.

129. Owen DR, Lewis AJ, Reynolds R, Rupprecht R, Eser D, Wilkins $\mathrm{MR}$, et al. Variation in binding affinity of the novel anxiolytic XBD173 for the $18 \mathrm{kDa}$ translocator protein in human brain. Synapse. 2011;65:257-9. https://doi.org/10.1002/syn.20884. 
130. Costa B, Pini S, Gabelloni P, Da Pozzo E, Abelli M, Lari L, et al. The spontaneous Ala147Thr amino acid substitution within the translocator protein influences pregnenolone production in lymphomonocytes of healthy individuals. Endocrinology. 2009;150:5438-45. https://doi.org/10.1210/en.2009-0752.

131. Prossin AR, Chandler M, Ryan KA, Saunders EF, Kamali M, Papadopoulos V, et al. Functional TSPO polymorphism predicts variance in the diurnal cortisol rhythm in bipolar disorder. Psychoneuroendocrinology. 2018;89:194-202. https://doi.org/ 10.1016/j.psyneuen.2018.01.013.

132. Fan J, Lindemann P, Feuilloley MG, Papadopoulos V. Structural and functional evolution of the translocator protein $(18 \mathrm{kDa})$. Curr Mol Med. 2012;12:369-86. https://doi.org/10.2174/ 1566524011207040369 .

133. Yeliseev AA, Kaplan S. A sensory transducer homologous to the mammalian peripheral-type benzodiazepine receptor regulates photosynthetic membrane complex formation in Rhodobacter sphaeroides 2.4.1. J Biol Chem. 1995;270:21167-75. https://doi. org/10.1074/jbc.270.36.21167.

134. Yeliseev AA, Krueger KE, Kaplan S. A mammalian mitochondrial drug receptor functions as a bacterial "oxygen" sensor. Proc Natl Acad Sci U S A. 1997;94:5101-6. https://doi.org/10.1073/ pnas.94.10.5101.

135. Fan J, Rone MB, Papadopoulos V. Translocator protein 2 is involved in cholesterol redistribution during erythropoiesis. J Biol Chem. 2009;284:30484-97. https://doi.org/10.1074/jbc.M109. 029876.

136. Betlazar C, Harrison-Brown M, Middleton RJ, Banati R, Liu GJ. Cellular sources and regional variations in the expression of the neuroinflammatory marker translocator protein (TSPO) in the normal brain. Int J Mol Sci. 2018;19. https://doi.org/10.3390/ ijms19092707.

137. Gong J, Szego EM, Leonov A, Benito E, Becker S, Fischer A, et al. Translocator protein ligand protects against neurodegeneration in the MPTP mouse model of Parkinsonism. J Neurosci. 2019;39:3752-69. https://doi.org/10.1523/JNEUROSCI.207018.2019 .

138. Lavisse S, Guillermier M, Herard AS, Petit F, Delahaye M, Van Camp N, et al. Reactive astrocytes overexpress TSPO and are detected by TSPO positron emission tomography imaging. J Neurosci. 2012;32:10809-18. https://doi.org/10.1523/ JNEUROSCI.1487-12.2012.

139. Pannell M, Economopoulos V, Wilson TC, Kersemans V, Isenegger PG, Larkin JR, et al. Imaging of translocator protein upregulation is selective for pro-inflammatory polarized astrocytes and microglia. Glia. 2019. https://doi.org/10.1002/glia. 23716.

140. Chiang T, Messing RO, Chou WH. Mouse model of middle cerebral artery occlusion. J Vis Exp. 2011. https://doi.org/10.3791/ 2761.

141. Pulagam KR, Colas L, Padro D, Plaza-Garcia S, Gomez-Vallejo $\mathrm{V}$, Higuchi M, et al. Evaluation of the novel TSPO radiotracer [(18)F] VUIIS1008 in a preclinical model of cerebral ischemia in rats. EJNMMI Res. 2017;7:93. https://doi.org/10.1186/ s13550-017-0343-7.

142. Rojas S, Martin A, Arranz MJ, Pareto D, Purroy J, Verdaguer E, et al. Imaging brain inflammation with [(11)C]PK11195 by PET and induction of the peripheral-type benzodiazepine receptor after transient focal ischemia in rats. J Cereb Blood Flow Metab. 2007;27:1975-86. https://doi.org/10.1038/sj.jcbfm.9600500.

143. Li HD, Li M, Shi E, Jin WN, Wood K, Gonzales R, et al. A translocator protein $18 \mathrm{kDa}$ agonist protects against cerebral ischemia/reperfusion injury. J Neuroinflammation. 2017;14:151. https://doi.org/10.1186/s12974-017-0921-7.

144. Constantinescu CS, Farooqi N, O'Brien K, Gran B. Experimental autoimmune encephalomyelitis (EAE) as a model for multiple sclerosis (MS). Br J Pharmacol. 2011;164:1079-106. https://doi. org/10.1111/j.1476-5381.2011.01302.x.

145. Torkildsen O, Brunborg LA, Myhr KM, Bo L. The cuprizone model for demyelination. Acta Neurol Scand Suppl. 2008;188: 72-6. https://doi.org/10.1111/j.1600-0404.2008.01036.x.

146. Banati RB, Newcombe J, Gunn RN, Cagnin A, Turkheimer F, Heppner F, et al. The peripheral benzodiazepine binding site in the brain in multiple sclerosis: quantitative in vivo imaging of microglia as a measure of disease activity. Brain. 2000;123(Pt 11):2321-37. https://doi.org/10.1093/brain/123.11.2321.

147. Nack A, Brendel M, Nedelcu J, Daerr M, Nyamoya S, Beyer C, et al. Expression of translocator protein and [18F]-GE180 ligand uptake in multiple sclerosis animal models. Cells. 2019;8. https:// doi.org/10.3390/cells8020094.

148. Zinnhardt B, Belloy M, Fricke IB, Orije J, Guglielmetti C, Hermann S, et al. Molecular imaging of immune cell dynamics during de- and remyelination in the cuprizone model of multiple sclerosis by [(18)F]DPA-714 PET and MRI. Theranostics. 2019;9:1523-37. https://doi.org/10.7150/thno.32461.

149. Daugherty DJ, Chechneva O, Mayrhofer F, Deng W. The hGFAPdriven conditional TSPO knockout is protective in a mouse model of multiple sclerosis. Sci Rep. 2016;6:22556. https://doi.org/10. 1038/srep22556.

150. Daugherty DJ, Selvaraj V, Chechneva OV, Liu XB, Pleasure DE, Deng W. A TSPO ligand is protective in a mouse model of multiple sclerosis. EMBO Mol Med. 2013;5:891-903. https://doi.org/ 10.1002/emmm.201202124.

151. Esquerda-Canals G, Montoliu-Gaya L, Guell-Bosch J, Villegas S. Mouse models of Alzheimer's disease. J Alzheimers Dis. 2017;57: 1171-83. https://doi.org/10.3233/JAD-170045.

152. James ML, Belichenko NP, Nguyen TV, Andrews LE, Ding Z, Liu $\mathrm{H}$, et al. PET imaging of translocator protein $(18 \mathrm{kDa})$ in a mouse model of Alzheimer's disease using N-(2,5dimethoxybenzyl)-2-18F-fluoro-N-(2-phenoxyphenyl)acetamide. J Nucl Med. 2015;56:311-6. https://doi.org/10.2967/jnumed.114. 141648.

153. Ji B, Maeda J, Sawada M, Ono M, Okauchi T, Inaji M, et al. Imaging of peripheral benzodiazepine receptor expression as biomarkers of detrimental versus beneficial glial responses in mouse models of Alzheimer's and other CNS pathologies. J Neurosci. 2008;28:12255-67. https://doi.org/10.1523/JNEUROSCI.231208.2008 .

154. Liu B, Le KX, Park MA, Wang S, Belanger AP, Dubey S, et al. In vivo detection of age- and disease-related increases in neuroinflammation by $18 \mathrm{~F}-$ GE180 TSPO MicroPET imaging in wildtype and Alzheimer's transgenic mice. J Neurosci. 2015;35: 15716-30. https://doi.org/10.1523/JNEUROSCI.0996-15.2015.

155. Mirzaei N, Tang SP, Ashworth S, Coello C, Plisson C, Passchier J, et al. In vivo imaging of microglial activation by positron emission tomography with [(11)C]PBR28 in the 5XFAD model of Alzheimer's disease. Glia. 2016;64:993-1006. https://doi.org/10. 1002/glia.22978.

156. Rapic S, Backes H, Viel T, Kummer MP, Monfared P, Neumaier $\mathrm{B}$, et al. Imaging microglial activation and glucose consumption in a mouse model of Alzheimer's disease. Neurobiol Aging. 2013;34:351-4. https://doi.org/10.1016/j.neurobiolaging.2012. 04.016 . 
157. Sacher C, Blume T, Beyer L, Peters F, Eckenweber F, Sgobio C, et al. Longitudinal PET monitoring of amyloidosis and microglial activation in a second generation amyloid-beta mouse model. $\mathrm{J}$ Nucl Med. 2019. https://doi.org/10.2967/jnumed.119.227322.

158. Serriere S, Tauber C, Vercouillie J, Mothes C, Pruckner C, Guilloteau D, et al. Amyloid load and translocator protein $18 \mathrm{kDa}$ in APPswePS1-dE9 mice: a longitudinal study. Neurobiol Aging. 2015;36:1639-52. https://doi.org/10.1016/j. neurobiolaging.2014.11.023.

159. Tournier BB, Tsartsalis S, Rigaud D, Fossey C, Cailly T, Fabis F, et al. TSPO and amyloid deposits in sub-regions of the hippocampus in the 3xTgAD mouse model of Alzheimer's disease. Neurobiol Dis. 2019;121:95-105. https://doi.org/10.1016/j.nbd. 2018.09.022.

160. Tournier BB, Tsartsalis S, Ceyzeriat K, Garibotto V, Millet P. In vivo TSPO signal and neuroinflammation in Alzheimer's disease. Cells. 2020;9. https://doi.org/10.3390/cells9091941.

161. Notter T, Coughlin JM, Gschwind T, Weber-Stadlbauer U, Wang Y, Kassiou M, et al. Translational evaluation of translocator protein as a marker of neuroinflammation in schizophrenia. Mol Psychiatry. 2018;23:323-34. https://doi.org/10.1038/mp.2016. 248.

162. Beckers L, Ory D, Geric I, Declercq L, Koole M, Kassiou M, et al. Increased expression of translocator protein (TSPO) marks proinflammatory microglia but does not predict neurodegeneration. Mol Imaging Biol. 2018;20:94-102. https://doi.org/10.1007/ s11307-017-1099-1.

163. Owen DR, Narayan N, Wells L, Healy L, Smyth E, Rabiner EA, et al. Pro-inflammatory activation of primary microglia and macrophages increases $18 \mathrm{kDa}$ translocator protein expression in rodents but not humans. J Cereb Blood Flow Metab. 2017;37:267990. https://doi.org/10.1177/0271678X17710182.

164. Tong J, Williams B, Rusjan PM, Mizrahi R, Lacapere JJ, Mccluskey T, et al. Concentration, distribution, and influence of aging on the $18 \mathrm{kDa}$ translocator protein in human brain: implications for brain imaging studies. J Cereb Blood Flow Metab. 2019:271678X19858003. https://doi.org/10.1177/ $0271678 X 19858003$.

165. Yokokura M, Terada T, Bunai T, Nakaizumi K, Takebayashi K, Iwata $\mathrm{Y}$, et al. Depiction of microglial activation in aging and dementia: positron emission tomography with [(11)C]DPA713 versus [(11)C]( R)PK11195. J Cereb Blood Flow Metab. 2017;37:877-89. https://doi.org/10.1177/0271678X16646788.

166. Paul S, Gallagher E, Liow JS, Mabins S, Henry K, Zoghbi SS, et al. Building a database for brain $18 \mathrm{kDa}$ translocator protein imaged using [(11)C]PBR28 in healthy subjects. J Cereb Blood Flow Metab. 2019;39:1138-47. https://doi.org/10.1177/ $0271678 X 18771250$.

167. Cosenza-Nashat M, Zhao ML, Suh HS, Morgan J, Natividad R, Morgello S, et al. Expression of the translocator protein of $18 \mathrm{kDa}$ by microglia, macrophages and astrocytes based on immunohistochemical localization in abnormal human brain. Neuropathol Appl Neurobiol. 2009;35:306-28. https://doi.org/10.1111/j. 1365-2990.2008.01006.x.

168. Werry EL, Bright FM, Piguet O, Ittner LM, Halliday GM, Hodges $\mathrm{JR}$, et al. Recent developments in TSPO PET imaging as a biomarker of neuroinflammation in neurodegenerative disorders. Int J Mol Sci. 2019;20. https://doi.org/10.3390/ijms20133161.

169. Peferoen LA, Vogel DY, Ummenthum K, Breur M, Heijnen PD, Gerritsen WH, et al. Activation status of human microglia is dependent on lesion formation stage and remyelination in multiple sclerosis. J Neuropathol Exp Neurol. 2015;74:48-63. https://doi. org/10.1097/NEN.0000000000000149.

170. Vogel DY, Vereyken EJ, Glim JE, Heijnen PD, Moeton M, van der Valk P, et al. Macrophages in inflammatory multiple sclerosis lesions have an intermediate activation status. J Neuroinflammation. 2013;10:35. https://doi.org/10.1186/17422094-10-35.

171. Zhang D, Hu X, Qian L, O'Callaghan JP, Hong JS. Astrogliosis in CNS pathologies: is there a role for microglia? Mol Neurobiol. 2010;41:232-41. https://doi.org/10.1007/s12035-010-8098-4.

172. Gui Y, Marks JD, Das S, Hyman BT, Serrano-Pozo A. Characterization of the $18 \mathrm{kDa}$ translocator protein (TSPO) expression in post-mortem normal and Alzheimer's disease brains. Brain Pathol. 2019. https://doi.org/10.1111/bpa.12763.

173. Xu J, Sun J, Perrin RJ, Mach RH, Bales KR, Morris JC, et al. Translocator protein in late stage Alzheimer's disease and dementia with Lewy bodies brains. Ann Clin Transl Neurol. 2019;6: 1423-34. https://doi.org/10.1002/acn3.50837.

174. Kuszpit K, Hollidge BS, Zeng X, Stafford RG, Daye S, Zhang X, et al. [(18)F]DPA-714 PET imaging reveals global neuroinflammation in Zika virus-infected mice. Mol Imaging Biol. 2018;20: 275-83. https://doi.org/10.1007/s11307-017-1118-2.

175. Doorduin J, Klein HC, Dierckx RA, James M, Kassiou M, de Vries EF. [11C]-DPA-713 and [18F]-DPA-714 as new PET tracers for TSPO: a comparison with [11C]-(R)-PK11195 in a rat model of herpes encephalitis. Mol Imaging Biol. 2009;11: 386-98. https://doi.org/10.1007/s11307-009-0211-6.

176. Parente A, Feltes PK, Vallez Garcia D, Sijbesma JW, Moriguchi Jeckel CM, Dierckx RA, et al. Pharmacokinetic analysis of 11CPBR28 in the rat model of herpes encephalitis: comparison with (R)-11C-PK11195. J Nucl Med. 2016;57:785-91. https://doi.org/ 10.2967/jnumed.115.165019.

177. Vallez Garcia D, de Vries EF, Toyohara J, Ishiwata K, Hatano K, Dierckx RA, et al. Evaluation of [(11)C]CB184 for imaging and quantification of TSPO overexpression in a rat model of herpes encephalitis. Eur J Nucl Med Mol Imaging. 2015;42:1106-18. https://doi.org/10.1007/s00259-015-3021-x.

178. Iaccarino L, Moresco RM, Presotto L, Bugiani O, Iannaccone S, Giaccone G, et al. An in vivo (11)C-(R)-PK11195 PET and in vitro pathology study of microglia activation in CreutzfeldtJakob disease. Mol Neurobiol. 2018;55:2856-68. https://doi.org/ 10.1007/s12035-017-0522-6.

179. De Picker LJ, Morrens M, Chance SA, Boche D. Microglia and brain plasticity in acute psychosis and schizophrenia illness course: a meta-review. Front Psychiatry. 2017;8:238. https://doi. org/10.3389/fpsyt.2017.00238.

180. Plaven-Sigray P, Matheson GJ, Coughlin JM, Hafizi S, Laurikainen H, Ottoy J, et al. Meta-analysis of the glial marker TSPO in psychosis revisited: reconciling inconclusive findings of patient-control differences. Biol Psychiatry. 2020. https://doi.org/ 10.1016/j.biopsych.2020.05.028.

181. Plaven-Sigray P, Cervenka S. Meta-analytic studies of the glial cell marker TSPO in psychosis - a question of apples and pears? Psychol Med. 2019;49:1624-8. https://doi.org/10.1017/ S003329171800421X.

182. Plaven-Sigray P, Matheson GJ, Collste K, Ashok AH, Coughlin JM, Howes OD, et al. Positron emission tomography studies of the glial cell marker translocator protein in patients with psychosis: a meta-analysis using individual participant data. Biol Psychiatry. 2018;84:433-42. https://doi.org/10.1016/j.biopsych.2018.02. 1171. 
183. Meyer JH, Cervenka S, Kim MJ, Kreisl WC, Henter ID, Innis RB. Neuroinflammation in psychiatric disorders: PET imaging and promising new targets. Lancet Psychiatry. 2020;7:1064-74. https://doi.org/10.1016/S2215-0366(20)30255-8.

184. Holmes SE, Hinz R, Conen S, Gregory CJ, Matthews JC, AntonRodriguez JM, et al. Elevated translocator protein in anterior cingulate in major depression and a role for inflammation in suicidal thinking: a positron emission tomography study. Biol Psychiatry. 2018;83:61-9. https://doi.org/10.1016/j.biopsych.2017.08.005.

185. Setiawan E, Attwells S, Wilson AA, Mizrahi R, Rusjan PM, Miler $\mathrm{L}$, et al. Association of translocator protein total distribution volume with duration of untreated major depressive disorder: a crosssectional study. Lancet Psychiatry. 2018;5:339-47. https://doi. org/10.1016/S2215-0366(18)30048-8.

186. Li H, Sagar AP, Keri S. Translocator protein (18 kDa TSPO) binding, a marker of microglia, is reduced in major depression during cognitive-behavioral therapy. Prog NeuroPsychopharmacol Biol Psychiatry. 2018;83:1-7. https://doi.org/ 10.1016/j.pnpbp.2017.12.011.

187. Scaini G, Barichello T, Fries GR, Kennon EA, Andrews T, Nix $\mathrm{BR}$, et al. TSPO upregulation in bipolar disorder and concomitant downregulation of mitophagic proteins and NLRP3 inflammasome activation. Neuropsychopharmacology. 2019;44: 1291-9. https://doi.org/10.1038/s41386-018-0293-4.

188. Weidner LD, Kannan P, Mitsios N, Kang SJ, Hall MD, Theodore $\mathrm{WH}$, et al. The expression of inflammatory markers and their potential influence on efflux transporters in drug-resistant mesial temporal lobe epilepsy tissue. Epilepsia. 2018;59:1507-17. https://doi.org/10.1111/epi.14505.

189. Tournier BB, Tsartsalis S, Ceyzeriat K, Medina Z, Fraser BH, Gregoire MC, et al. Fluorescence-activated cell sorting to reveal the cell origin of radioligand binding. J Cereb Blood Flow Metab. 2020;40:1242-55. https://doi.org/10.1177/0271678X19860408.

190. Tournier BB, Tsartsalis S, Ceyzeriat K, Fraser BH, Gregoire MC, Kovari E, et al. Astrocytic TSPO upregulation appears before microglial TSPO in Alzheimer's disease. J Alzheimers Dis. 2020. https://doi.org/10.3233/JAD-200136.

191. Notter T, Coughlin JM, Gschwind T, Weber-Stadlbauer U, Wang $\mathrm{Y}$, Kassiou M, et al. Translational evaluation of translocator protein as a marker of neuroinflammation in schizophrenia. Mol Psychiatry. 2017. https://doi.org/10.1038/mp.2016.248.

Publisher's note Springer Nature remains neutral with regard to jurisdictional claims in published maps and institutional affiliations. 